\title{
Diverse signatures of deformation, pressure-temperature and anatexis in the Rayagada sector of the Eastern Ghats granulite terrane
}

\author{
S K SEN ${ }^{1}$ and S BHATTACHARYA ${ }^{2}$ \\ ${ }^{1}$ Department of Geological Sciences, Jadavpur University, Calcutta, India \\ ${ }^{2}$ Geological Studies Unit, Indian Statistical Institute, Calcutta, India
}

\begin{abstract}
The granulites and granitoids around Rayagada in the north central part of the Eastern Ghats belt display structural and petrological differences when compared to similar rocks from Chilka and Jenapore in the northern Eastern Ghats. The impress of $F_{1}$ deformation is almost erased while that of $F_{3}$ is muted. The metapelites have a restricted chemical range and are non-migmatitic. There are two varieties of leptynitic granitoids, one of which is interlayered with yet another S-type granite containing cordierite. The maximum recorded temperature from geothermometers is $780^{\circ} \mathrm{C}$, but the magnitude of pressure is comparatively low, the highest value being $6.3 \mathrm{kbar}$. Another distinctive feature of the pressuretemperature record is the absence of evidence of decompression in the lower realms of pressure and temperature. Metamorphic reactions that could be identified indicate cooling, a noteworthy reaction being the sillimanite to andalusite transformation. Integration of data from pressure-temperature sensors suggest cooling at two pressures, 6 and $5 \mathrm{kbar}$. The generation of two types of granitoids from metapelites is interpreted to be due to intersection with solidus curves for pelitic and graywacke-like compositions, constrained by recent experiments, at 6 and $5 \mathrm{kbar}$. The first melting occurred on a prograde path while the second one was due to increase in temperature during exhumation at tectonic rates.

Thus inspite of a broad similarity in the geodynamic scenario across the northern part of the Eastern Ghat belt, differences in exhumation rates and in style of melting were responsible for producing different signatures in the Rayagada granulite terrane.
\end{abstract}

\section{Introduction}

The Eastern Ghats belt of the Indian Precambrian extends over a length of about $1500 \mathrm{~km}$ and is dominated by quartzofeldspathic and metapelitic granulites and granitoids. A broad commonality of structure and petrology is evident across the belt, but significant differences exist between several sectors. For a comprehensive understanding of the evolution of this large granulite terrane as well as of the Eastern Ghats belt, the differences in the signatures will have to be accounted for. In the last two decades details from several terrains within this belt have become available, though vital information on the ubiquitous granitoids have been seriously lacking (Dasgupta et al 1994; Bhattacharya 1997). With a view to filling this gap, the present authors investigated the Chilka Lake granulites and advanced a scheme of evolution of the Eastern Ghats granulites on the basis of structure, petrology and geochemistry of the critical rock types (Bhattacharya et al 1994; Sen and Bhattacharya 1997). In a quest for developing an integrated picture of the evolution of the granulites and granitoids of the northern part of the Eastern Ghats belt, two more critical areas were selected for detailed study, one of them being around Rayagada in the north central part of the Eastern Ghats and the other around Jenapore in the northern sector (Kar et al 2000). This study

Keywords. Eastern Ghats granulites; cordierite granite; anatexis at two PT; exhumation rates. 
reports several significant findings on the Rayagada rocks which warrant a more complex reconstruction of the evolution of at least this part of the belt.

In the following pages it will be shown that the Rayagada rocks possess several distinctive features. First, the deformation pattern is characterised by a prominence of $F_{2}$ folds, and a weak development of $F_{3}$ structures. Second, the peak pressures registered by the granulites are relatively low. Third, the last stages of the pressure-temperature record are best interpreted in terms of cooling rather than decompression. Fourth, two S-type granites of different composition, evidently produced by anatexis, occur, at places in an interlayered fashion. Furthermore, one of the additional purposes of this communication is correcting and modifying some information and interpretation published by Shaw and Arima $(1996,1998)$ on this area.

\section{Field relations and structure}

Figure 1 shows the different rock types and the structures of the granulite terrain around Rayagada. It is evident from the map that the mesoscopic fold pattern is determined largely by the second deformation $F_{2}$. The metapelitic granulites, including quartzites and calc-granulites and the charnockites-enderbites are characterised by a pervasive gneissic foliation, $S_{1}$, which defines the major $F_{2}$ folds. Many of the $F_{2}$ folds are isoclinal and occasionally overturned (figure 1). Unlike the two other sectors of the northern Eastern Ghats, e.g. Chilka Lake and Jenapore $\left(20^{\circ} 7^{\prime} \mathrm{N}, 85^{\circ} 28^{\prime} \mathrm{E}\right.$ and $20^{\circ} 51^{\prime} \mathrm{N}, 86^{\circ} 2^{\prime} \mathrm{E}$ respectively), the impress of the $F_{1}$ and $F_{3}$ folds is muted. In the map published by Shaw and Arima (1996), a large area in the northwest has been shown to be occupied by leptynite and sillimanite-granite. Our investigations have revealed that the major rock type in these parts of the area are leptynites (garnetiferous granitoids) containing pods and bands of a cordierite-bearing granitoid (figure 2) that can be defined within narrow compositional limits. The maximum dimensions of the cordieritebearing granitoids are about $2.0 \times 0.25 \mathrm{~m}$ and occasional interbanding with leptynite on finer scales produce a migmatitic appearance (figure 3 ). The enclosing leptynites have a well-developed plättung texture resulting in a foliation corresponding to $S_{2}$. The leptynite exposures trend parallel to the gneissic foliation $S_{1}$ in the adjacent khondalites (metapelitic gneisses with garnet and sillimanite). But interestingly the two foliations are distinctly at an angle (figure 4).

\section{Petrography}

Though the Rayagada area is dominated by metapelites and granitoids, a variety of rocks is present.
These are charnockite-enderbites, basic granulites, calc-granulites, quartzites and porphyritic granites. Calc-granulites and quartzites form layers within the metapelites, and porphyritic granites are later intrusives, containing xenoliths of earlier rocks. In this paper the charnockite-enderbites, basic granulites and porphyritic granites will not be covered in any detail; however, geothermometric and geobarometric results obtained from charnockites and basic granulites will be utilised.

The dominant metapelitic rocks of the area have the general assemblage garnet-sillimanite-quartz-alkali feldspar-ilmenite/magnetite (rarely rutile). Non-albitic plagioclase is absent, alkali feldspar varies in the range $\mathrm{Or}_{77-89}$. Spinels, in some rocks Zn-rich, occur as inclusions as well as independent grains commonly associated with Fe-Ti oxides. A few metapelites have been found to have cordierite of a composition different from cordierites of granitoids (table 4).

There are no assemblages characteristic of $\mathrm{Mg}-\mathrm{Al}$ rich granulites within the metapelites. These assemblages have been reported from several areas in the southern part of the Eastern Ghats belt, they are characterised by sapphirine, aluminous orthopyroxene and spinel (Dasgupta et al 1994; Sen et al 1995). Shaw and Arima (1996) reported corundum + quartz assembalges occurring in small lenses in metapelites of this area, the present authors could not confirm this finding. Small granules of corundum, associated with titaniferous magnetite and $\mathrm{Fe}-\mathrm{Al}$ spinel are rarely present and are possibly products of oxidation of spinel to magnetite.

The dominant variety of granitoid (leptynite) present in this area is a gneiss with garnet-alkali feldspar- plagioclase- quartz- biotite- Fe-Ti oxides with high alkali feldspar : plagioclase ratio. These are leucocratic, medium to fine grained gneisses commonly with platy granoblastic textures. In some spots inclusions of charnockites within leptynites are common, but the overall structure is non-migmatitic. Sillimanite inclusions within garnets in leptynite are rare, but significant as described below.

The other variety of granitoid occurs as inclusions arranged in a layer-like fashion within leptynites. Petrographically, they are characterised by cordierite and substantial amounts of plagioclase. This variety of granitoid displays complex textures such as biotitesillimanite intergrowths bordering cordierites and garnet-ilmenite symplectites. Biotites of two distinct compositions are present, and a mineral intermediate between cordierite and osumilite in composition occur as light brownish subhedral to anhedral grains. The latter are possibly alteration products of cordierites, or, less likely of osumilites. A very significant finding is the detection, by optical methods, of andalusite in three samples of cordierite-granites.

The calc-granulites have a general granoblastic texture on which compositional banding has been 


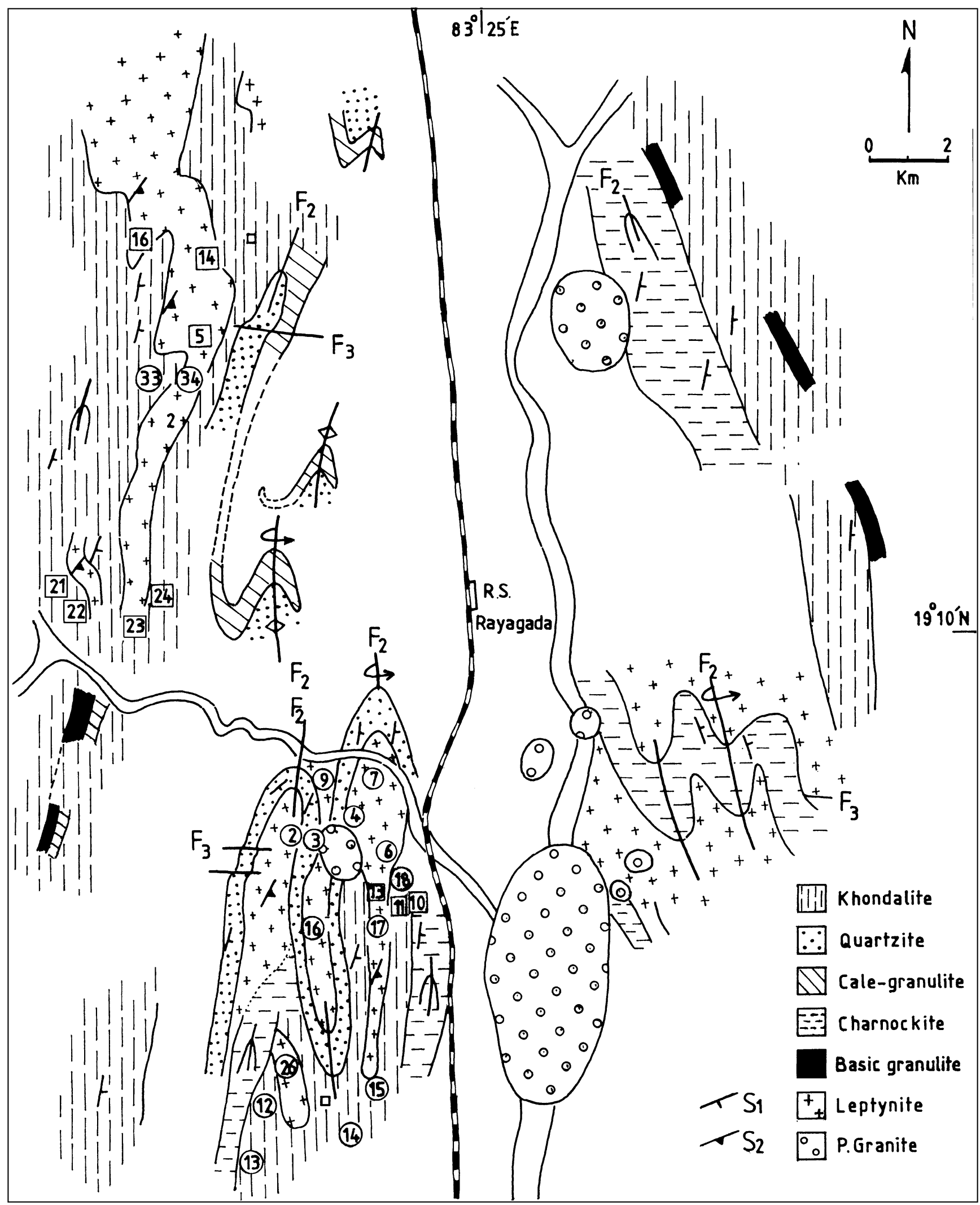

Figure 1. Geological map of the Rayagada area. P. Granite indicates porphyritic granite. For further details of structures see Bhattacharya (1997). Sample locations in numerals: encircled-R/95 series, enclosed within squares-R/97 series.

superimposed. The assemblage is diopside-plagioclase $\left(\mathrm{an}_{80-82}\right)$-scapolite $\left(\mathrm{me}_{80-83}\right)$-wollastonite-sphene-calcite \pm garnet $\left(\mathrm{gr}_{90}\right)$.
In the charnockite-enderbite group of rocks, which commonly form massive exposures, the mineral assemblage is hypersthene-plagioclase- alkali feldspar- 


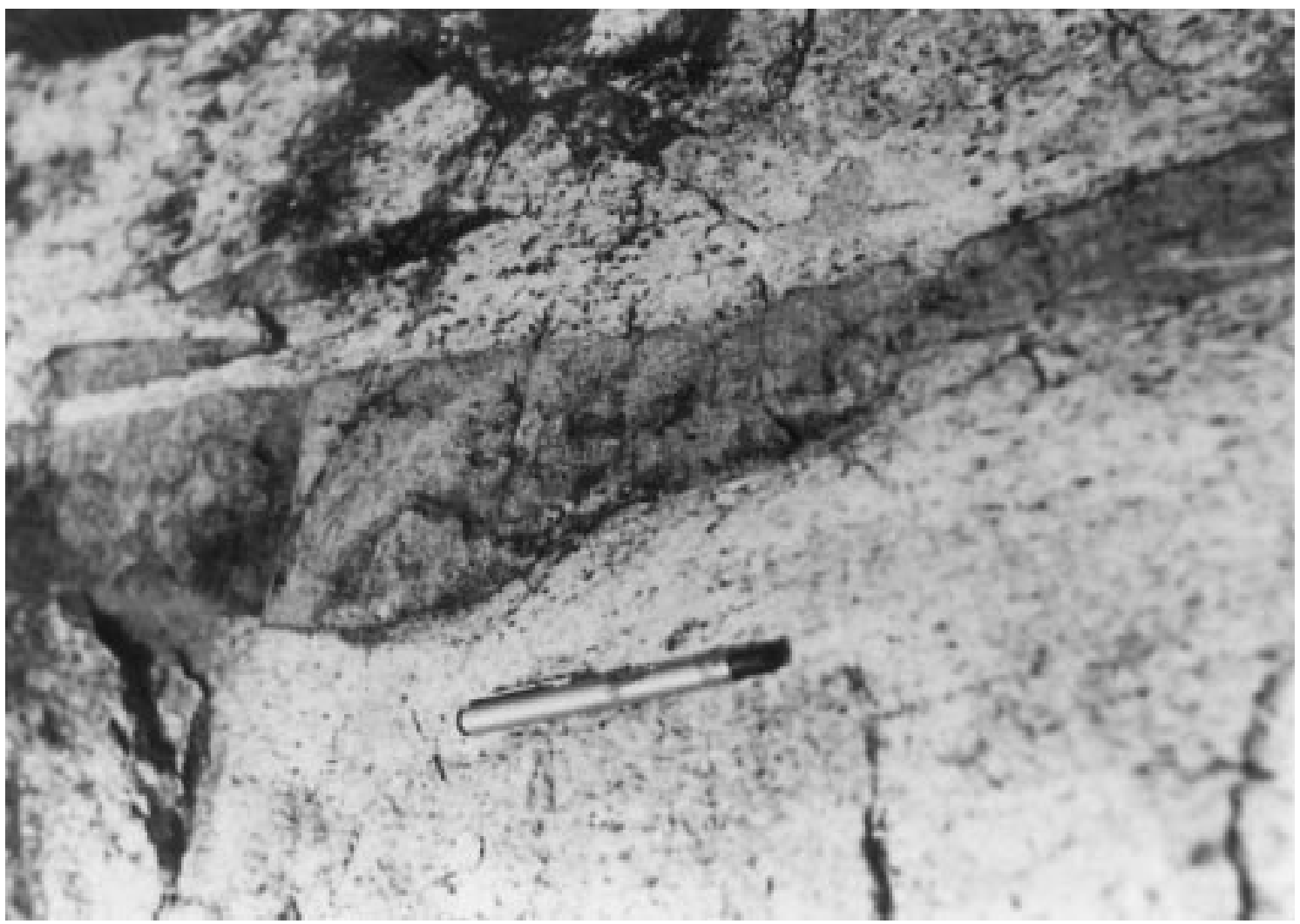

Figure 2. Dark cordierite-granite layers within leptynites (L-1); foliations in leptynite parallel to pen.

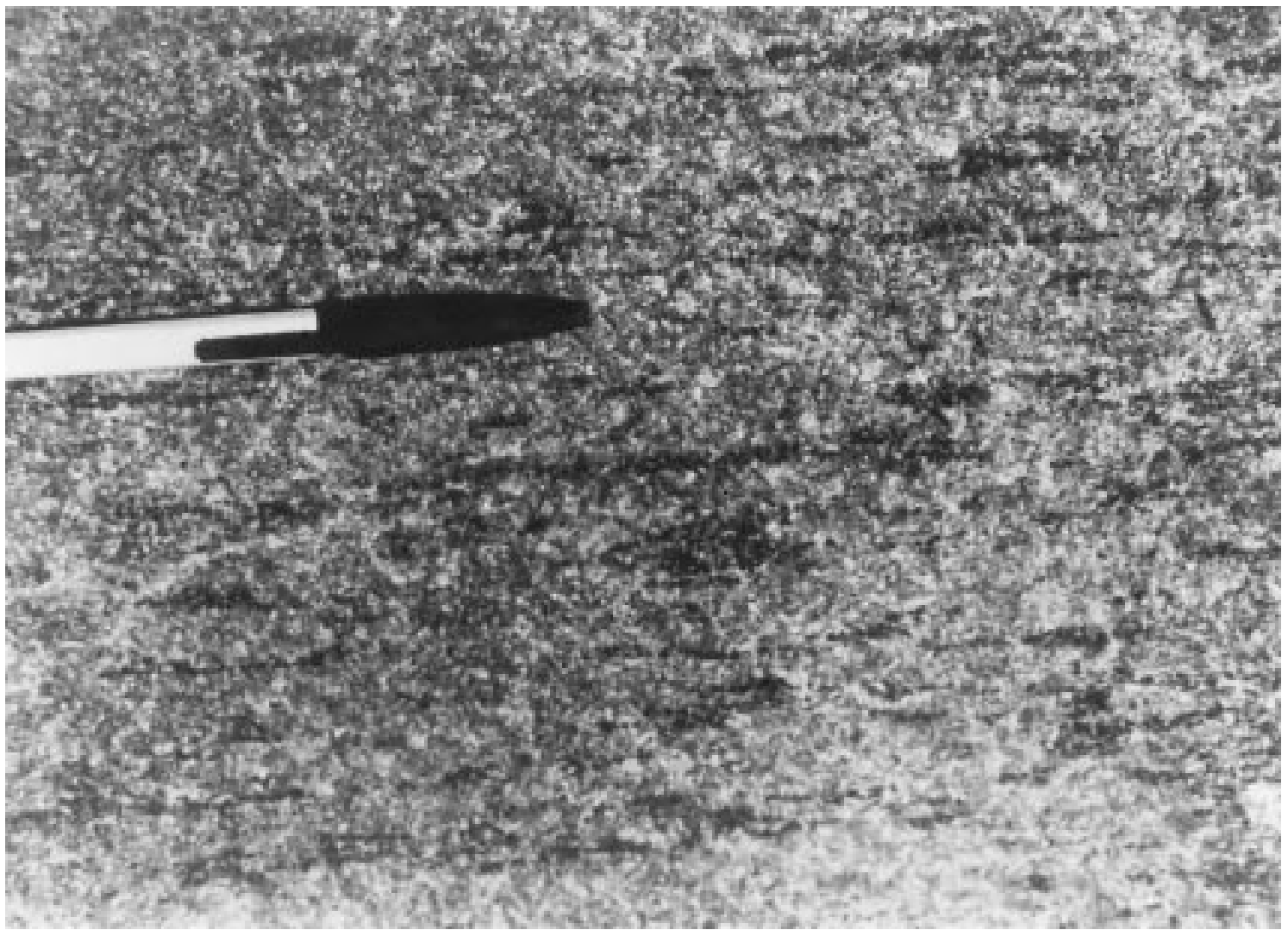

Figure 3. Fine scale interlayering, in a pseudo-migmatitic fashion, between cordierite-granites and leptynites. 


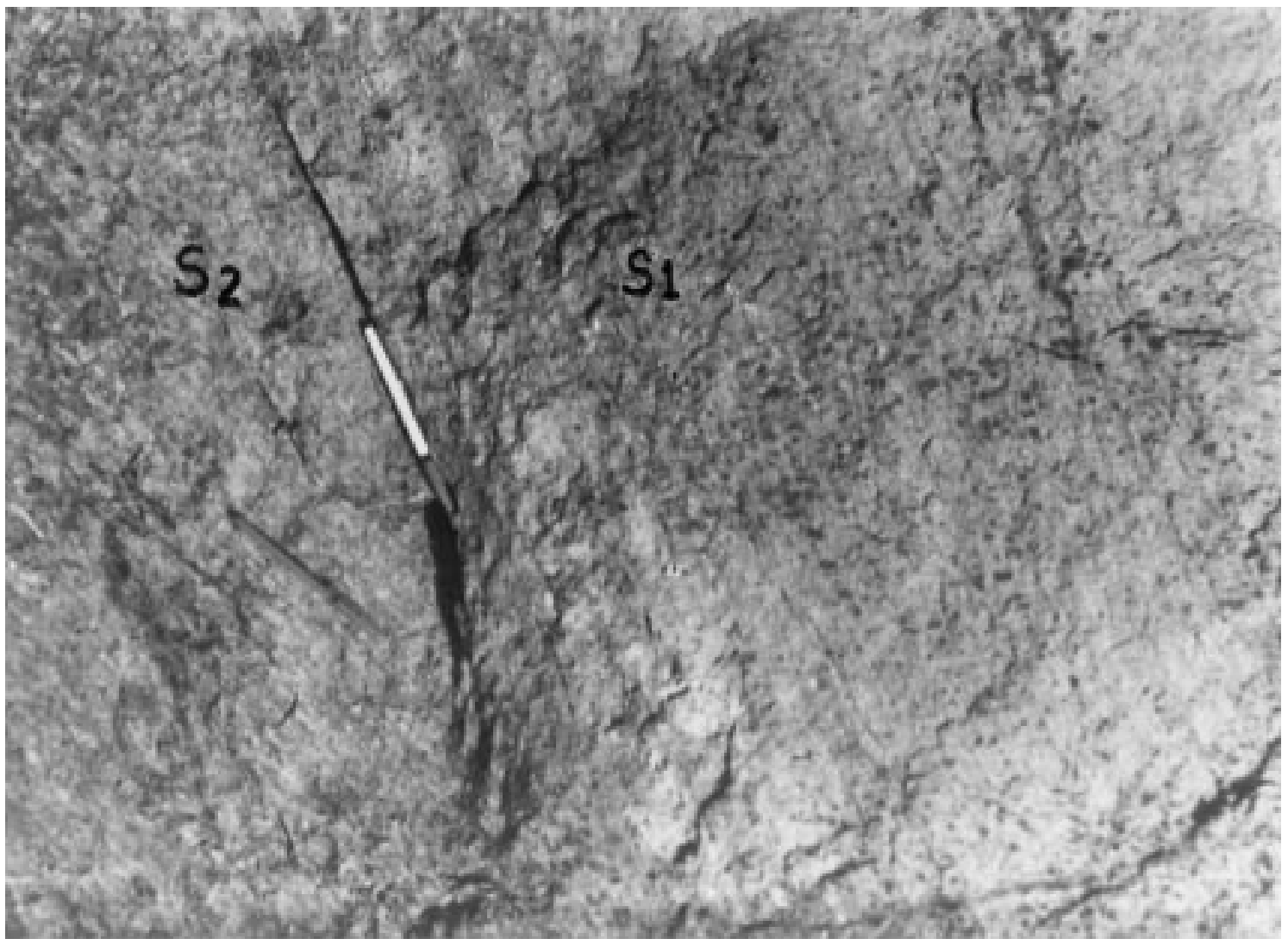

Figure 4. $S_{2}$ in leptynites (left) at an angle with $S_{1}$ in adjoining khondalites (right).

biotite- Fe-Ti oxides \pm garnet. Myrmekites and dactylitic intergrowths of garnet and quartz are common. The basic granulites which form small lenses and pods are of two varieties: hornblende-pyroxene granulites and two-pyroxene granulites. Two rather unusual features characterise the hornblende pyroxene granulites - the absence of orthopyroxene and presence of highly anorthitic plagioclase $\left(\mathrm{an}_{85-90}\right)$.

\section{Mineral chemistry}

Mineral phases from twenty-two rocks were analysed by EPMA with the dual purpose of constraining metamorphic reactions and estimating pressure-temperature values from mineral geothermometers and geobarometers. Sixty representative EPMA analyses of different silicates and oxides are presented in tables 1 to 8 .

Garnet: All the garnets analysed are almandinerich and poor in $\mathrm{Ca}$ and $\mathrm{Mn}$ with the grossularite and spessartine contents never exceeding 6 mole $\%$. The pyrope contents range from 20 to 30 mole per cent approximately. In the garnets from khondalites pyrope varies from 18 to 31 per cent. In most of the cordieritegranites pyrope contents is within a narrow range, e.g. $27 \pm 03$ mole\%. Garnets of different compositions have been found in one sample of cordierite-granite. The analysis of garnet from a leptynite (table 1) was carried out by the SEM-EDAX method. There is no significant difference between core and rim compositions of the analysed garnets.

Cordierite: The cordierites are highly magnesian, those from the cordierite-granite are extremely close in $\mathrm{X}_{\mathrm{Mg}}$ values, e.g. 0.82 to 0.84 . Cordierite occurs rarely in the khondalites and has a lower $\mathrm{X}_{\mathrm{Mg}}(0.75$, table 2$)$. The alkali contents, especially $\mathrm{K}$ is very low. No significant difference between core and rim compositions was detected.

Spinel: The $\mathrm{X}_{\mathrm{Mg}}$ values of spinels in the present rocks vary from 0.24 to 0.48 . Some of these spinels may contain up to $15 \mathrm{wt} \%$ of $\mathrm{ZnO}$. Shaw and Arima (1996) subdivided spinel-bearing assemblages into Ferich and Fe-poor varieties and correlated the $\mathrm{Fe}$ concentration in spinel with the assemblages. On the basis of our analytical data this correlation can be questioned, because the range of $\mathrm{X}_{\mathrm{Mg}}$ values in spinels of the two groups are practically the same. In several rocks spinel grains of different compositions have been encountered, examples of such disequilibrium compositions have been given in table 4 .

Biotite: The biotites from both cordierite-granite and khondalite are dominantly magnesian and have high Ti contents. It is common to find biotites of two compositions in these rocks; out of these, those marked as biotite- 1 in table 3 are less magnesian. They occur 


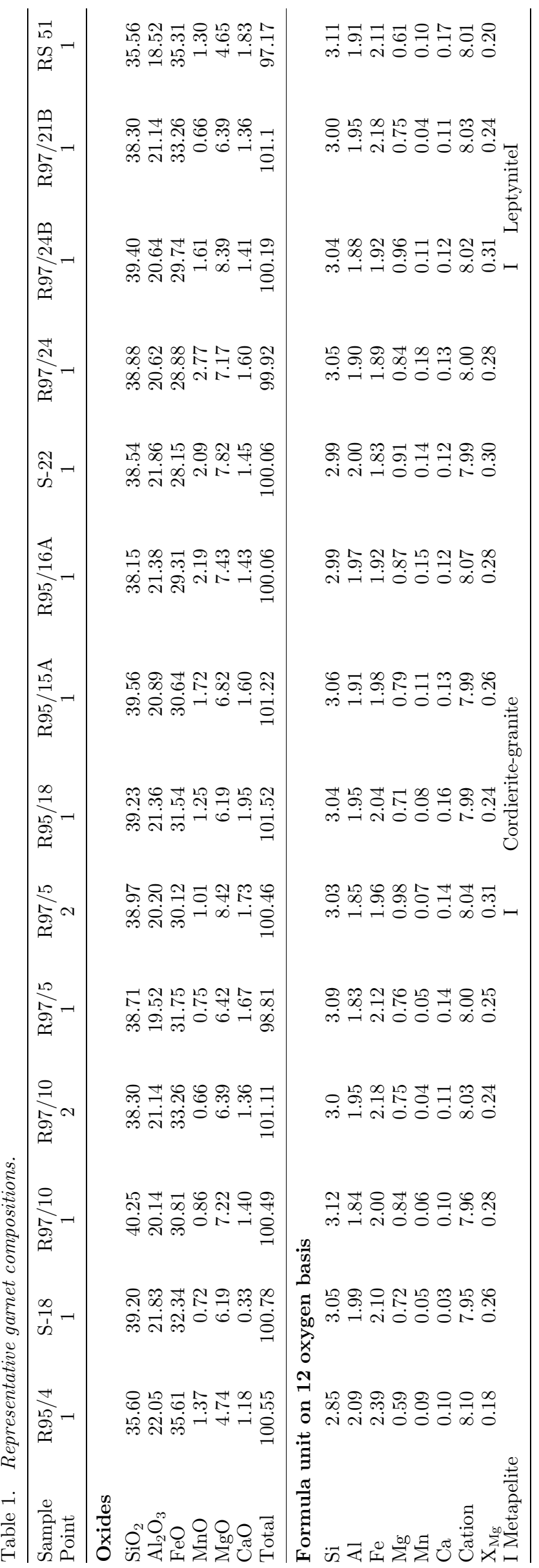


Table 2. Representative biotite compositions.

\begin{tabular}{|c|c|c|c|c|c|c|}
\hline $\begin{array}{l}\text { Sample no. } \\
\text { Grain type } \\
\text { Oxides \% }\end{array}$ & $\begin{array}{c}\mathrm{R} 95 / 16 \mathrm{a} \\
1\end{array}$ & $\begin{array}{c}\mathrm{R} 95 / 16 \mathrm{a} \\
2\end{array}$ & $\begin{array}{c}\text { R95/34 } \\
1 \\
\text { Cordierite granite }\end{array}$ & $\begin{array}{c}\mathrm{R} 95 / 34 \\
2\end{array}$ & $\begin{array}{c}\mathrm{R} 97 / 22 \\
1\end{array}$ & $\begin{array}{c}\text { R97/11 } \\
2 \\
\text { Khondalite }\end{array}$ \\
\hline $\begin{array}{l}\mathrm{SiO}_{2} \\
\mathrm{Al}_{2} \mathrm{O}_{3} \\
\mathrm{FeO} \\
\mathrm{MgO} \\
\mathrm{MnO} \\
\mathrm{CaO} \\
\mathrm{K}_{2} \mathrm{O} \\
\mathrm{Na}_{2} \mathrm{O} \\
\mathrm{TiO}_{2} \\
\text { Total }\end{array}$ & $\begin{array}{r}35.63 \\
15.95 \\
16.46 \\
12.25 \\
0.18 \\
0.13 \\
9.46 \\
- \\
6.44 \\
96.53\end{array}$ & $\begin{array}{r}34.87 \\
16.17 \\
13.05 \\
13.87 \\
0.05 \\
0.22 \\
9.57 \\
0.35 \\
4.74 \\
92.90\end{array}$ & $\begin{array}{r}34.64 \\
16.45 \\
14.93 \\
12.27 \\
0.04 \\
0.04 \\
9.61 \\
0.27 \\
5.29 \\
93.53\end{array}$ & $\begin{array}{c}35.94 \\
16.86 \\
12.60 \\
15.18 \\
- \\
0.06 \\
9.65 \\
0.22 \\
4.15 \\
94.66\end{array}$ & $\begin{array}{c}35.27 \\
15.25 \\
18.67 \\
9.83 \\
- \\
- \\
9.74 \\
- \\
5.63 \\
94.39\end{array}$ & $\begin{array}{c}36.44 \\
16.14 \\
16.52 \\
11.04 \\
- \\
- \\
9.67 \\
- \\
4.08 \\
93.89\end{array}$ \\
\hline \multicolumn{7}{|c|}{ Formula unit on 20 oxygen basis } \\
\hline $\begin{array}{l}\mathrm{Si} \\
\mathrm{Al} \\
\mathrm{Fe} \\
\mathrm{Mg} \\
\mathrm{Mn} \\
\mathrm{Ca} \\
\mathrm{K} \\
\mathrm{Na} \\
\mathrm{Ti} \\
\text { Cation sum } \\
\mathrm{X}_{\mathrm{Mg}}\end{array}$ & $\begin{array}{r}4.83 \\
2.55 \\
1.87 \\
2.48 \\
0.02 \\
0.02 \\
1.64 \\
- \\
0.66 \\
14.07 \\
0.57\end{array}$ & $\begin{array}{r}4.85 \\
2.65 \\
1.52 \\
2.88 \\
0.01 \\
0.03 \\
1.70 \\
0.09 \\
0.49 \\
14.22 \\
0.65\end{array}$ & $\begin{array}{r}4.83 \\
2.70 \\
1.74 \\
2.55 \\
0.01 \\
0.01 \\
1.71 \\
0.07 \\
0.55 \\
14.17 \\
0.59\end{array}$ & $\begin{array}{r}4.87 \\
2.69 \\
1.43 \\
3.07 \\
- \\
0.01 \\
1.67 \\
0.06 \\
0.42 \\
14.22 \\
0.68\end{array}$ & $\begin{array}{c}4.95 \\
2.52 \\
2.19 \\
2.06 \\
- \\
- \\
1.74 \\
- \\
0.59 \\
14.05 \\
0.53\end{array}$ & $\begin{array}{c}5.06 \\
2.64 \\
1.92 \\
2.29 \\
- \\
- \\
1.71 \\
- \\
0.43 \\
14.05 \\
0.60\end{array}$ \\
\hline
\end{tabular}

Grain type 1 independent; and type 2 intergrown.

Table 3. Representative cordierite composition.

\begin{tabular}{|c|c|c|c|c|c|c|}
\hline $\begin{array}{l}\text { Sample no. } \\
\text { Oxides \% }\end{array}$ & $\mathrm{R} 95 / 16 \mathrm{c}$ & $\mathrm{R} 95 / 34$ & $\begin{array}{c}\mathrm{R} 95 / 17 \mathrm{~b} \\
\text { Cordierite-granite }\end{array}$ & $\mathrm{R} 95 / 16 \mathrm{a}$ & $\mathrm{R} 97 / 24 \mathrm{~b}$ & $\begin{array}{c}\text { S-18 } \\
\text { Khondalite }\end{array}$ \\
\hline $\mathrm{SiO}_{2}$ & 49.95 & 49.57 & 49.65 & 48.91 & 49.47 & 49.14 \\
\hline $\mathrm{TiO}_{2}$ & 0.01 & $<0.01$ & 0.02 & 0.01 & - & $<0.01$ \\
\hline $\mathrm{Al}_{2} \mathrm{O}_{3}$ & 31.91 & 32.40 & 32.90 & 32.72 & 31.34 & 33.43 \\
\hline $\mathrm{FeO}$ & 4.34 & 4.20 & 3.99 & 5.08 & 4.48 & 6.06 \\
\hline $\mathrm{MnO}$ & 0.10 & - & 0.22 & 0.15 & - & 0.06 \\
\hline $\mathrm{MgO}$ & 10.85 & 11.08 & 12.09 & 12.51 & 11.66 & 10.27 \\
\hline $\mathrm{CaO}$ & 0.02 & 0.05 & 0.17 & 0.03 & 0.04 & 0.04 \\
\hline $\mathrm{Na}_{2} \mathrm{O}$ & - & 0.07 & 0.11 & 0.14 & 0.31 & 0.09 \\
\hline Total & 96.98 & 97.38 & 99.15 & 99.54 & 97.34 & 99.09 \\
\hline \multicolumn{7}{|c|}{ Formula unit on 18 oxygen basis } \\
\hline $\mathrm{Si}$ & 5.07 & 5.05 & 4.98 & 4.92 & 5.06 & 4.97 \\
\hline $\mathrm{Al}$ & 3.86 & 3.89 & 3.89 & 3.88 & 3.78 & 3.98 \\
\hline $\mathrm{Fe}$ & 0.37 & 0.36 & 0.34 & 0.43 & 0.37 & 0.51 \\
\hline $\mathrm{Mg}$ & 1.66 & 1.68 & 1.81 & 1.88 & 1.78 & 1.55 \\
\hline $\mathrm{Mn}$ & 0.01 & - & 0.02 & 0.01 & - & 0.01 \\
\hline $\mathrm{Ca}$ & $<0.01$ & 0.01 & 0.02 & - & - & $<0.01$ \\
\hline $\mathrm{Na}$ & - & 0.01 & 0.02 & 0.02 & 0.06 & 0.01 \\
\hline $\mathrm{Ti}$ & - & - & - & - & - & - \\
\hline Cation sum & 10.99 & 11.01 & 11.08 & 11.12 & 11.08 & 11.05 \\
\hline $\mathrm{X}_{\mathrm{Mg}}$ & 0.82 & 0.82 & 0.84 & 0.83 & 0.83 & 0.75 \\
\hline
\end{tabular}

either as inclusions within garnets or as independent grains not intergrown with sillimanite. Biotite- 2 is richer in magnesium and poorer in Ti than biotite-1.

Feldspar: The chemical data on alkali feldspar is not reported here, but as mentioned earlier they are Krich with the potassium component between $\mathrm{Or}_{77-89}$. Plagioclase feldspars were not found in khondalites, and in leptynites the compositions, as determined optically, straddle the boundary between oligoclase and andesine.

Chemical analyses of three plagioclase feldspars from cordierite-granite are presented in table 5 .

Fe-Ti Oxides: Different oxide phases are observed in both khondalites and cordierite-granites, and we report here four analysed phases from five rock samples (table 6). Ilmenites have variable magnesium 
Table 4. Representative spinel compositions.

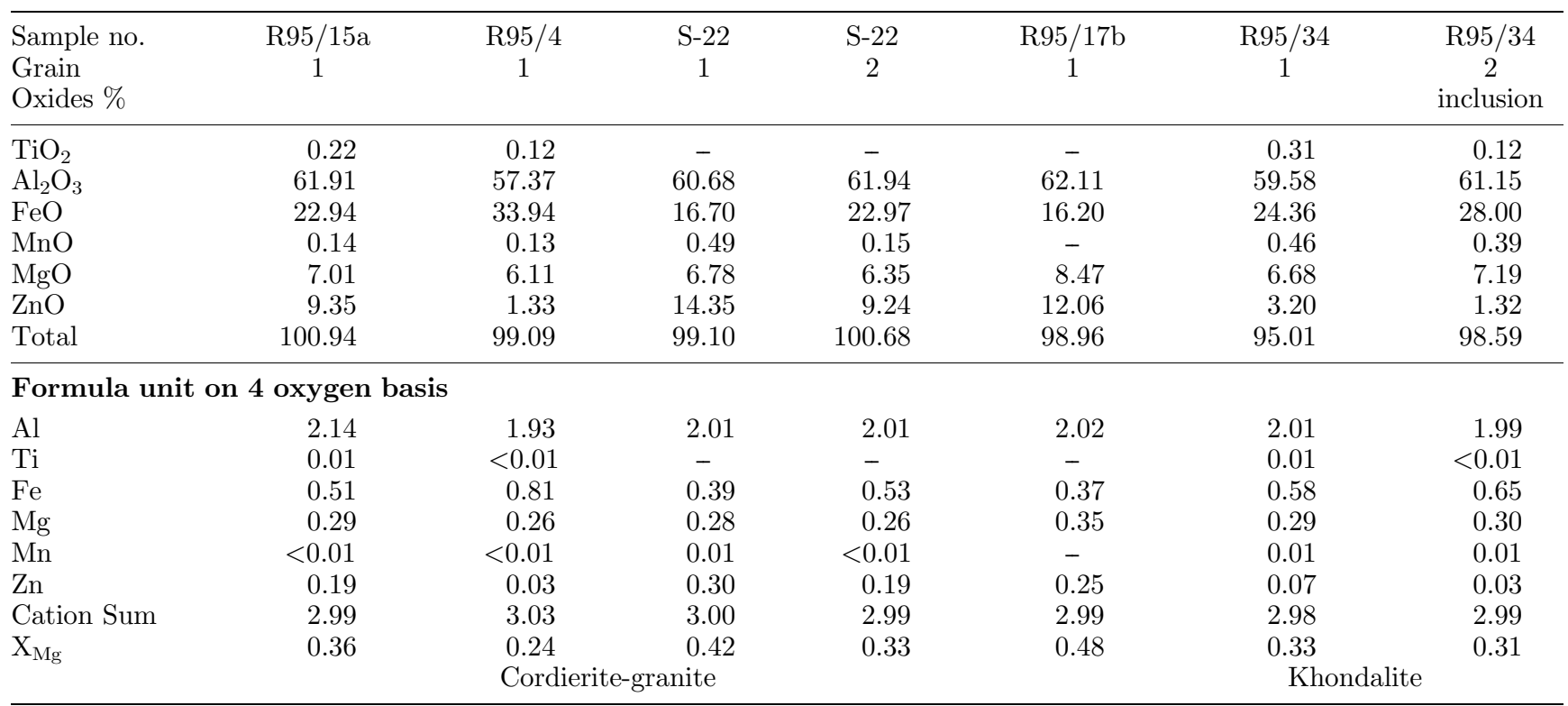

Table 5. Representative plagioclase feldspar and quasi-osumilite/quasi-cordierite compositions.

\begin{tabular}{|c|c|c|c|c|c|c|c|}
\hline $\begin{array}{l}\text { Sample no. } \\
\text { Oxides } \%\end{array}$ & $\begin{array}{l}\text { R95/17b } \\
\text { Plag }\end{array}$ & $\begin{array}{l}\mathrm{R} 97 / 21 \mathrm{~b} \\
\quad \text { Plag }\end{array}$ & $\begin{array}{l}\text { R97/24b } \\
\text { Plag }\end{array}$ & $\begin{array}{c}\mathrm{R} 95 / 16 \mathrm{c} \\
\text { q-osu }\end{array}$ & $\begin{array}{c}\mathrm{R} 95 / 16 \mathrm{a} \\
\text { q-osu }\end{array}$ & $\begin{array}{c}\mathrm{R} 95 / 16 \mathrm{c} \\
\text { q-crd }\end{array}$ & $\begin{array}{c}\mathrm{R} 95 / 16 \mathrm{a} \\
\text { q-crd }\end{array}$ \\
\hline $\mathrm{SiO}_{2}$ & 54.18 & 60.29 & 58.20 & 50.28 & 43.62 & 50.28 & 43.62 \\
\hline $\mathrm{Al}_{2} \mathrm{O}_{3}$ & 28.03 & 23.45 & 24.56 & 29.45 & 31.94 & 29.45 & 31.94 \\
\hline $\mathrm{FeO}$ & - & - & - & 5.35 & 5.07 & 5.35 & 5.07 \\
\hline $\mathrm{MgO}$ & - & - & - & 4.24 & 7.12 & 4.24 & 7.12 \\
\hline $\mathrm{CaO}$ & 11.03 & 6.48 & 7.89 & 1.63 & 0.72 & 1.63 & 0.72 \\
\hline $\mathrm{Na}_{2} \mathrm{O}$ & 5.38 & 9.11 & 7.84 & 0.45 & 0.43 & 0.45 & 0.43 \\
\hline $\mathrm{K}_{2} \mathrm{O}$ & 0.13 & 0.15 & 0.12 & 0.62 & 1.68 & 0.62 & 1.68 \\
\hline Total & 98.74 & 99.48 & 98.61 & 92.01 & 90.57 & 92.01 & 90.57 \\
\hline No. of oxygens & 8 & 8 & 8 & 30 & 30 & 18 & 18 \\
\hline $\mathrm{Si}$ & 2.48 & 2.71 & 2.65 & 9.09 & 8.14 & 5.45 & 4.88 \\
\hline Al IV & 1.51 & 1.24 & 1.32 & 2.91 & 3.86 & 3.76 & 4.21 \\
\hline $\mathrm{Al} \mathrm{VI}$ & - & - & - & 3.36 & 3.16 & -- & -- \\
\hline $\mathrm{Fe}$ & - & - & - & 0.81 & 0.79 & 0.49 & 0.47 \\
\hline $\mathrm{Mg}$ & - & - & - & 1.14 & 1.98 & 0.69 & 1.19 \\
\hline $\mathrm{Ca}$ & 0.54 & 0.31 & 0.38 & 0.31 & 0.14 & 0.19 & 0.09 \\
\hline $\mathrm{Na}$ & 0.48 & 0.79 & 0.67 & 0.16 & 0.16 & 0.09 & 0.09 \\
\hline $\mathrm{K}$ & 0.01 & 0.01 & 0.01 & 0.14 & 0.40 & 0.09 & 0.24 \\
\hline Cation sum & 5.01 & 5.07 & 5.04 & 17.93 & 18.63 & 10.76 & 11.17 \\
\hline $\mathrm{X}_{\mathrm{An}} / \mathrm{X}_{\mathrm{Mg}}$ & 0.52 & 0.28 & 0.35 & 0.58 & 0.71 & 0.58 & 0.71 \\
\hline
\end{tabular}

and manganese contents; magnetites are stoichiometric with $\mathrm{Fe}^{+2} \cdot / \mathrm{Fe}^{+3}$ nearly 0.5 ; rutile contains significant $\mathrm{Fe}^{+2}$. Additionally, exsolution in $\mathrm{Fe}-\mathrm{Ti}$ oxides is quite common; hemo-ilmenite is occasionally found as a separate phase.

"Quasi-Cordierite": A mineral somewhat resembling cordierite was found in several cordieritegranite. They occur as light brownish, non-pleochroic, subhedral grains with low birefringence $(\sim 0.004)$. Under the microscope they appear to be heterogeneous with parts of the grains lamellar in habit. But SEM investigations did not reveal any chemical heterogeneity.

Two of the results of EPMA analysis of this mineral is given in table 5. The analytical data show that chemically the mineral is intermediate between cordierite and osumilite. In terms of relative proportions, $(\mathrm{Mg}+\mathrm{Fe})$ is closer to osumilite than cordierite, while it is the opposite with $\mathrm{Si}$ and $\mathrm{Al}$. The analytical totals leave a lot of room for $\mathrm{H}_{2} \mathrm{O}$ and $\mathrm{CO}_{2}$, but no significant amount of $\mathrm{CO}_{2}$ was detected. $\mathrm{H}_{2} \mathrm{O}$ of about $5 \%$ or more is not admissible in either cordierite or osumilite (Olsen and Bunch 1970). Ca contents are high, and the possibility of submicroscopic intergrowth of Ca-bearing phases like plagioclase was eliminated by SEM investigation. $(\mathrm{Na}+\mathrm{K})$ is high for cordierite and low for osumilite. The low amounts and fine grain size precluded identifying the mineral by high resolution physical methods like X-ray diffractometry. The best, though not satisfactory, interpretation that can 


\begin{tabular}{|c|c|}
\hline 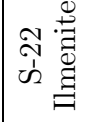 & 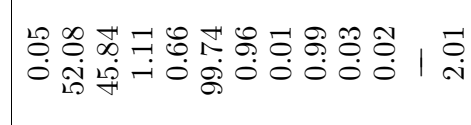 \\
\hline 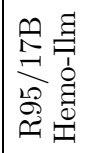 & 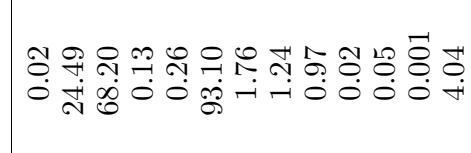 \\
\hline 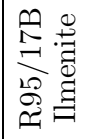 & 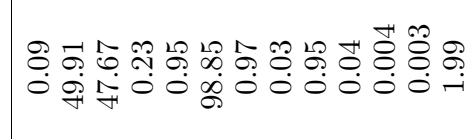 \\
\hline 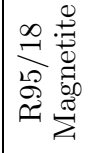 & 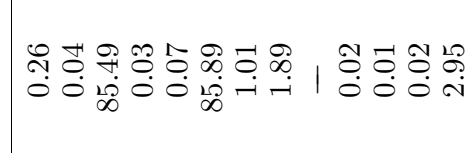 \\
\hline 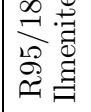 & 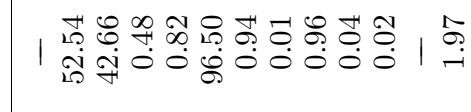 \\
\hline 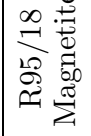 & 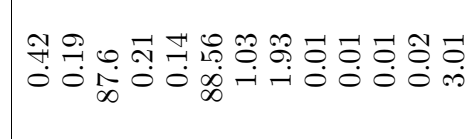 \\
\hline 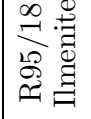 & 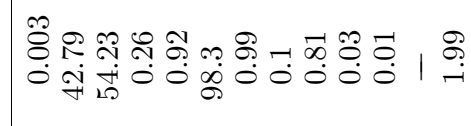 \\
\hline 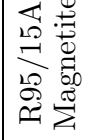 & 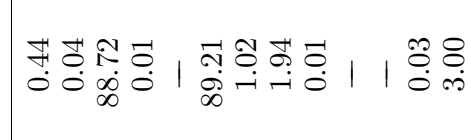 \\
\hline 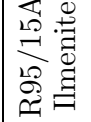 & 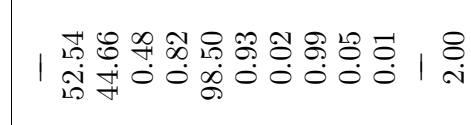 \\
\hline 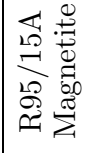 & 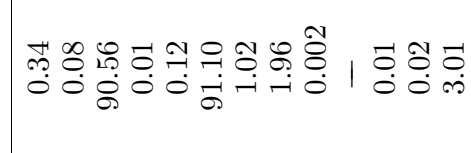 \\
\hline 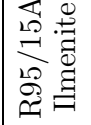 & 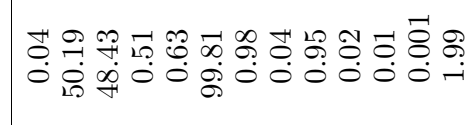 \\
\hline 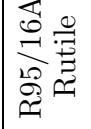 & 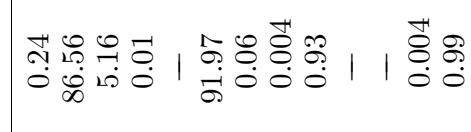 \\
\hline 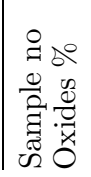 & 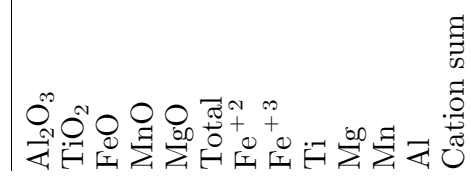 \\
\hline
\end{tabular}


Table 7. Coexisting Garnet-Orthopyroxene-Plagioclase composition.

\begin{tabular}{|c|c|c|c|c|c|c|c|c|c|c|}
\hline \multirow{2}{*}{$\begin{array}{l}\text { Sample no } \\
\text { Mineral } \\
\text { Oxides \% }\end{array}$} & \multicolumn{5}{|c|}{$\mathrm{R} 95 / 14 \mathrm{C}$} & \multicolumn{5}{|c|}{$\mathrm{R} 97 / 3$} \\
\hline & $\begin{array}{l}\text { Grt } \\
\text { core }\end{array}$ & $\begin{array}{l}\text { Opx } \\
\text { core }\end{array}$ & $\begin{array}{l}\text { Grt } \\
\text { rim }\end{array}$ & $\underset{\text { rim }}{\text { Opx }}$ & $\begin{array}{l}\text { Plag } \\
\text { core }\end{array}$ & $\begin{array}{l}\text { Grt } \\
\text { core }\end{array}$ & $\begin{array}{l}\text { Opx } \\
\text { core }\end{array}$ & $\begin{array}{l}\text { Grt } \\
\text { rim }\end{array}$ & $\begin{array}{c}\text { Opx } \\
\text { rim }\end{array}$ & $\begin{array}{l}\text { Plag } \\
\text { core }\end{array}$ \\
\hline $\mathrm{SiO}_{2}$ & 38.11 & 49.13 & 37.50 & 51.28 & 60.21 & 37.44 & 51.54 & 37.96 & 51.44 & 57.06 \\
\hline $\mathrm{Al}_{2} \mathrm{O}_{3}$ & 19.88 & 1.08 & 19.52 & 0.58 & 22.55 & 20.05 & 0.44 & 20.05 & 0.40 & 24.39 \\
\hline $\mathrm{FeO}$ & 34.87 & 36.20 & 33.56 & 34.51 & - & 30.50 & 32.92 & 29.74 & 32.59 & - \\
\hline $\mathrm{MgO}$ & 3.54 & 13.06 & 3.74 & 13.91 & - & 3.82 & 14.84 & 4.09 & 15.45 & - \\
\hline $\mathrm{MnO}$ & 1.05 & 0.31 & 1.10 & 0.33 & - & 2.28 & 0.93 & 2.48 & 0.97 & - \\
\hline $\mathrm{CaO}$ & 3.30 & 0.41 & 3.60 & 0.32 & 6.12 & 5.32 & 0.64 & 5.27 & 0.59 & 8.57 \\
\hline $\mathrm{Na}_{2} \mathrm{O}$ & - & 0.01 & - & - & 8.84 & - & 0.06 & - & - & 7.04 \\
\hline $\mathrm{K}_{2} \mathrm{O}$ & - & 0.07 & - & - & 0.15 & - & 0.02 & - & - & 0.21 \\
\hline \multirow[t]{2}{*}{ Total } & 100.74 & 100.38 & 99.03 & 100.95 & 97.88 & 99.41 & 101.38 & 97.49 & 101.44 & 97.22 \\
\hline & $12(\mathrm{O})$ & $6(\mathrm{O})$ & $12(\mathrm{O})$ & $6(\mathrm{O})$ & $8(\mathrm{O})$ & $12(\mathrm{O})$ & $6(\mathrm{O})$ & $12(\mathrm{O})$ & $6(\mathrm{O})$ & $8(\mathrm{O})$ \\
\hline $\mathrm{Si}$ & 3.04 & 1.96 & 3.04 & 2.00 & 2.74 & 3.04 & 1.99 & 3.08 & 1.99 & 2.63 \\
\hline $\mathrm{Al}$ & 1.87 & 0.05 & 1.87 & 0.03 & 1.21 & 1.89 & 0.02 & 1.86 & 0.02 & 1.33 \\
\hline $\mathrm{Fe}$ & 2.33 & 1.21 & 2.28 & 1.13 & - & 1.99 & 1.07 & 1.86 & 1.05 & - \\
\hline $\mathrm{Mg}$ & 0.42 & 0.77 & 0.45 & 0.81 & - & 0.49 & 0.86 & 0.39 & 0.89 & - \\
\hline $\mathrm{Mn}$ & 0.07 & 0.01 & 0.08 & 0.01 & - & 0.17 & 0.03 & 0.16 & 0.03 & - \\
\hline $\mathrm{Ca}$ & 0.28 & 0.02 & 0.31 & 0.01 & 0.30 & 0.45 & 0.03 & 0.65 & 0.02 & 0.42 \\
\hline $\mathrm{Na}$ & - & - & - & - & 0.78 & - & - & - & - & 0.63 \\
\hline $\mathrm{K}$ & - & - & - & - & 0.01 & - & - & - & - & 0.01 \\
\hline Cation sum & 8.02 & 4.02 & 8.03 & 3.99 & 5.05 & 8.02 & 4.00 & 7.99 & 4.00 & 5.03 \\
\hline $\mathrm{X}_{\mathrm{Mg}}$ & 0.13 & 0.39 & 0.14 & 0.42 & $\mathrm{X}_{\mathrm{an}} 0.28$ & 0.16 & 0.45 & 0.13 & 0.46 & $\mathrm{X}_{\mathrm{an}} 0.40$ \\
\hline
\end{tabular}

Table 8. Coexisitng Pyroxene composition.

\begin{tabular}{|c|c|c|c|c|c|c|}
\hline \multirow{2}{*}{$\begin{array}{l}\text { Sample no } \\
\text { Mineral } \\
\text { Oxides \% }\end{array}$} & \multicolumn{2}{|c|}{$\mathrm{R} 97 / 2 \mathrm{~A}$} & \multicolumn{2}{|c|}{$\mathrm{R} 97 / 17 \mathrm{~B}$} & \multicolumn{2}{|c|}{ RN73 } \\
\hline & Opx & $\mathrm{Cpx}$ & Opx & Cpx & Opx(host) & Cpx(lamelle) \\
\hline $\mathrm{SiO}_{2}$ & 51.88 & 53.09 & 50.21 & 51.44 & 48.82 & 49.57 \\
\hline $\mathrm{Al}_{2} \mathrm{O}_{3}$ & 0.73 & 1.42 & 0.67 & 1.10 & 0.45 & 0.93 \\
\hline $\mathrm{FeO}$ & 25.02 & 7.86 & 28.15 & 9.35 & 37.09 & 17.54 \\
\hline $\mathrm{MgO}$ & 19.75 & 13.83 & 19.02 & 12.46 & 9.83 & 8.15 \\
\hline $\mathrm{MnO}$ & 0.83 & 0.23 & 0.66 & 0.23 & 1.03 & 0.47 \\
\hline $\mathrm{CaO}$ & 0.48 & 23.05 & 0.57 & 23.19 & 1.15 & 20.28 \\
\hline $\mathrm{Na}_{2} \mathrm{O}$ & 0.03 & 0.12 & 0.05 & 0.19 & 0.04 & 0.25 \\
\hline $\mathrm{K}_{2} \mathrm{O}$ & 0.03 & 0.01 & 0.01 & 0.05 & -- & -- \\
\hline $\mathrm{TiO}_{2}$ & 0.18 & 0.27 & 0.18 & 0.42 & 0.12 & 0.08 \\
\hline Total & 98.84 & 99.80 & 99.51 & 98.42 & 98.54 & 97.26 \\
\hline \multicolumn{7}{|c|}{ Formula unit on 6 oxygen basis } \\
\hline $\mathrm{Si}$ & 1.98 & 1.98 & 1.94 & 1.97 & 2.00 & 1.98 \\
\hline $\mathrm{Al}$ & 0.03 & 0.06 & 0.03 & 0.05 & 0.02 & 0.04 \\
\hline $\mathrm{Fe}$ & 0.80 & 0.25 & 0.91 & 0.30 & 1.27 & 0.59 \\
\hline $\mathrm{Mg}$ & 1.13 & 0.77 & 1.10 & 0.71 & 0.60 & 0.49 \\
\hline $\mathrm{Mn}$ & 0.03 & 0.01 & 0.02 & 0.01 & 0.04 & 0.02 \\
\hline $\mathrm{Ca}$ & 0.02 & 0.92 & 0.02 & 0.95 & 0.05 & 0.87 \\
\hline $\mathrm{Na}$ & -- & 0.01 & -- & 0.01 & -- & 0.02 \\
\hline K & -- & -- & -- & -- & -- & -- \\
\hline $\mathrm{Ti}$ & -- & 0.01 & 0.01 & 0.01 & -- & -- \\
\hline Cation sum & 4.00 & 3.99 & 4.04 & 4.01 & 3.98 & 4.04 \\
\hline $\mathrm{X}_{\mathrm{Mg}}$ & 0.59 & 0.75 & 0.55 & 0.70 & 0.32 & 0.45 \\
\hline
\end{tabular}

be offered on the basis of the data is that this is an alteration product of cordierite or osumilite. Alteration by simple hydration is unable to explain the chemistry irrespective of the starting material, so we suggest that the alteration could have been due to interaction between cordierite and granitic melt. The possibility that the mineral is the product of interac- tion between osumilite and melt is discounted because the physical conditions were not favourable for the stability of osumilite (Carrington and Harley 1995a). We have styled the mineral as quasi-cordierite because it is, in its optical and chemical characters, "intermediate" between cordierite and osumilite and perhaps closer to cordierite. 


\section{Metamorphic reactions}

When compared with the metamorphic reactions documented or suggested from the granulites of other areas of the Eastern Ghats, two features of Rayagada granulites stand out. First, cooling appears to be a common trigger for several metamorphic reactions recorded by the Rayagada rocks. Second, evidence for the decompression reaction (garnet + sillimanite + quartz $\rightarrow$ cordierite) reported from a large number of granulite terrains within the Eastern Ghats is lacking here.

Garnet-sillimanite intergrowths separating spinel and quartz suggest that the following generalized reaction took place (figure 5):

$$
\text { spinel }+ \text { quartz } \rightarrow \text { garnet }+ \text { sillimanite }
$$

Spinel and quartz grains are separated by garnets and larger grains of sillimanite in several metapelites pointing to the same reaction (figure 6). Though our sampling was extensive, no evidence for the reaction corundum + quartz $\rightarrow$ sillimanite, reported by Shaw and Arima (1996) could be detected.

In cordierite-granites, a complex reaction involving biotites of two compositions offers the best explanation for the biotite-sillimanite intergrowths and garnetilmenite symplectites observed in these rocks. Figure 7 shows biotite-sillimanite intergrowths bordering cordierite grains with more magnesian biotite (biotite-2), while garnet-ilmenite symplectites are observed in the same rock (figure 8). Using the compositions of the analysed phases, the following balanced reaction can be written (table 1 to 8 ):

$$
\begin{aligned}
& 0.5 \text { cordierite }+1.62 \text { biotite- } 1+0.17 \text { quartz } \\
& \quad=1.0 \text { biotite- } 2+0.20 \text { sillimanite }+0.50 \text { garnet } \\
& \quad+0.07 \text { ilmenite }+0.52 \text { K-feldspar }
\end{aligned}
$$

Pereira and Bea (1994) proposed a reaction of this kind, but the chemical trends of biotites in their rocks were different. Cordierites in these granitoids have virtually a constant composition $\left(\mathrm{X}_{\mathrm{Mg}}=0.81\right.$ to 0.83$)$, we interpret this as the result of equilibrium between several $\mathrm{Mg}-\mathrm{Fe}$ solid solutions in a reaction with high variance. This reaction is a cordierite "breakdown" reaction; interestingly there is no evidence for subsolidus formation of cordierite in these rocks.

The rare presence of andalusite in some cordieritegranites appears to be due to the polymorphic transition:

sillimanite $\rightarrow$ andalusite

Figure 9 shows andalusite possibly pseudomorphing sillimanite. In the same rock andalusite's presence was suspected within mats of sillimanite, but owing to the very small size of the grains, it could not be confirmed beyond doubt.

Among charnockite-enderbites and basic granulites two sets of mineral reactions are noteworthy. The first is the garnet forming reaction observed commonly in

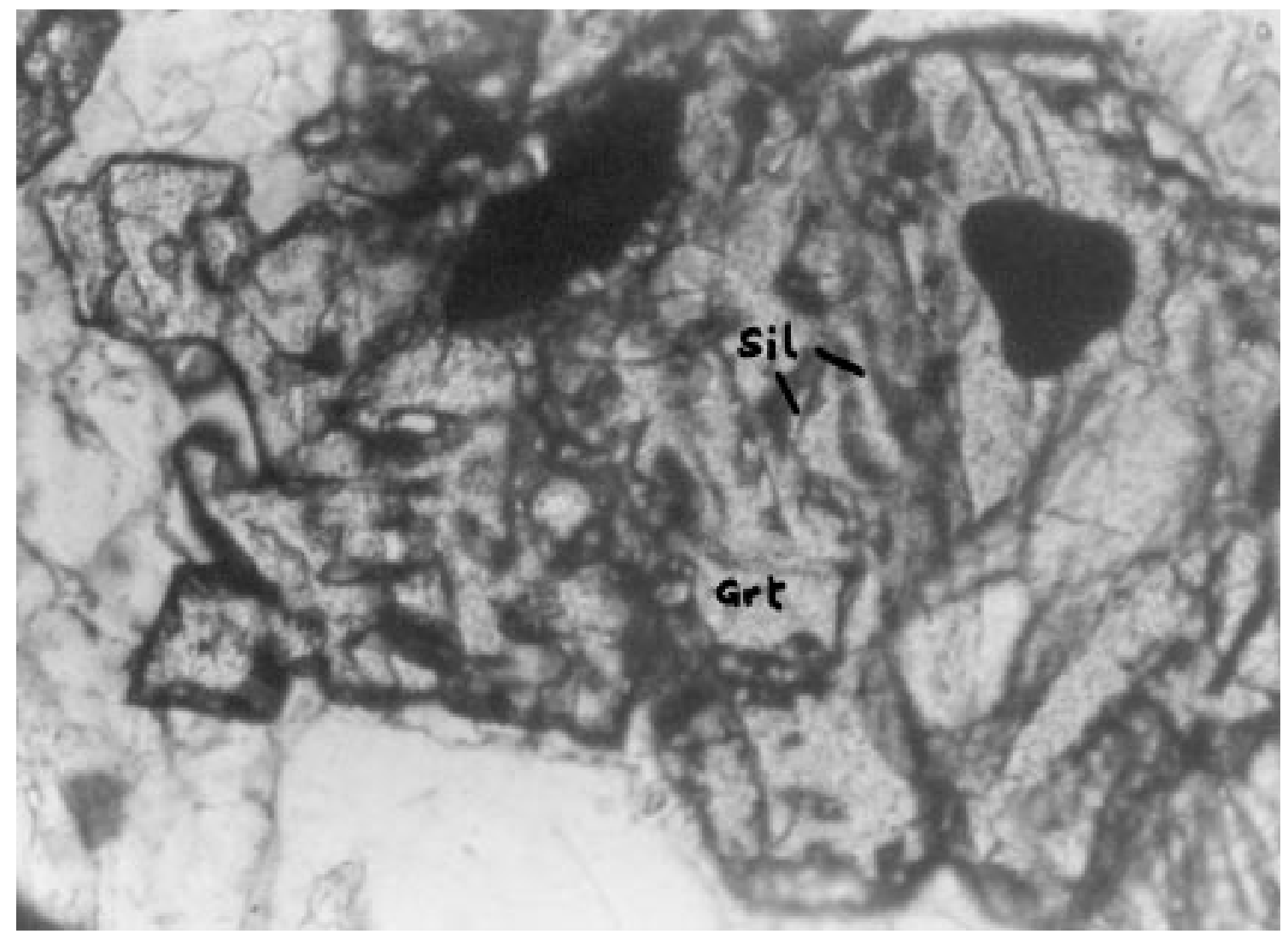

Figure 5. Photomicrograph showing sillimanite intergrowths with garnet in an almost dactylic manner. X:120. 


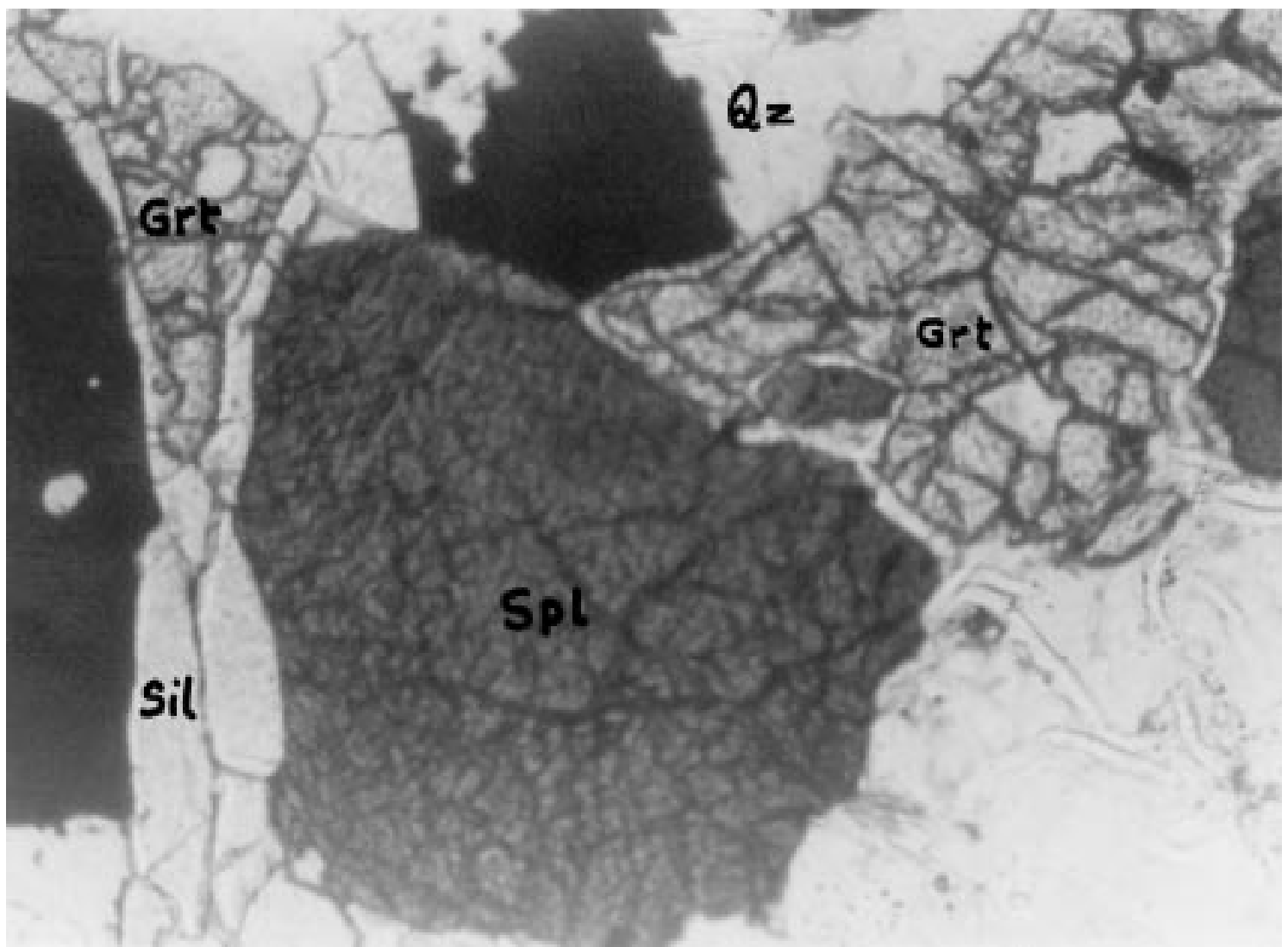

Figure 6. Photomicrograph showing spinel and quartz separated by garnet and sillimanite grains. X:120.

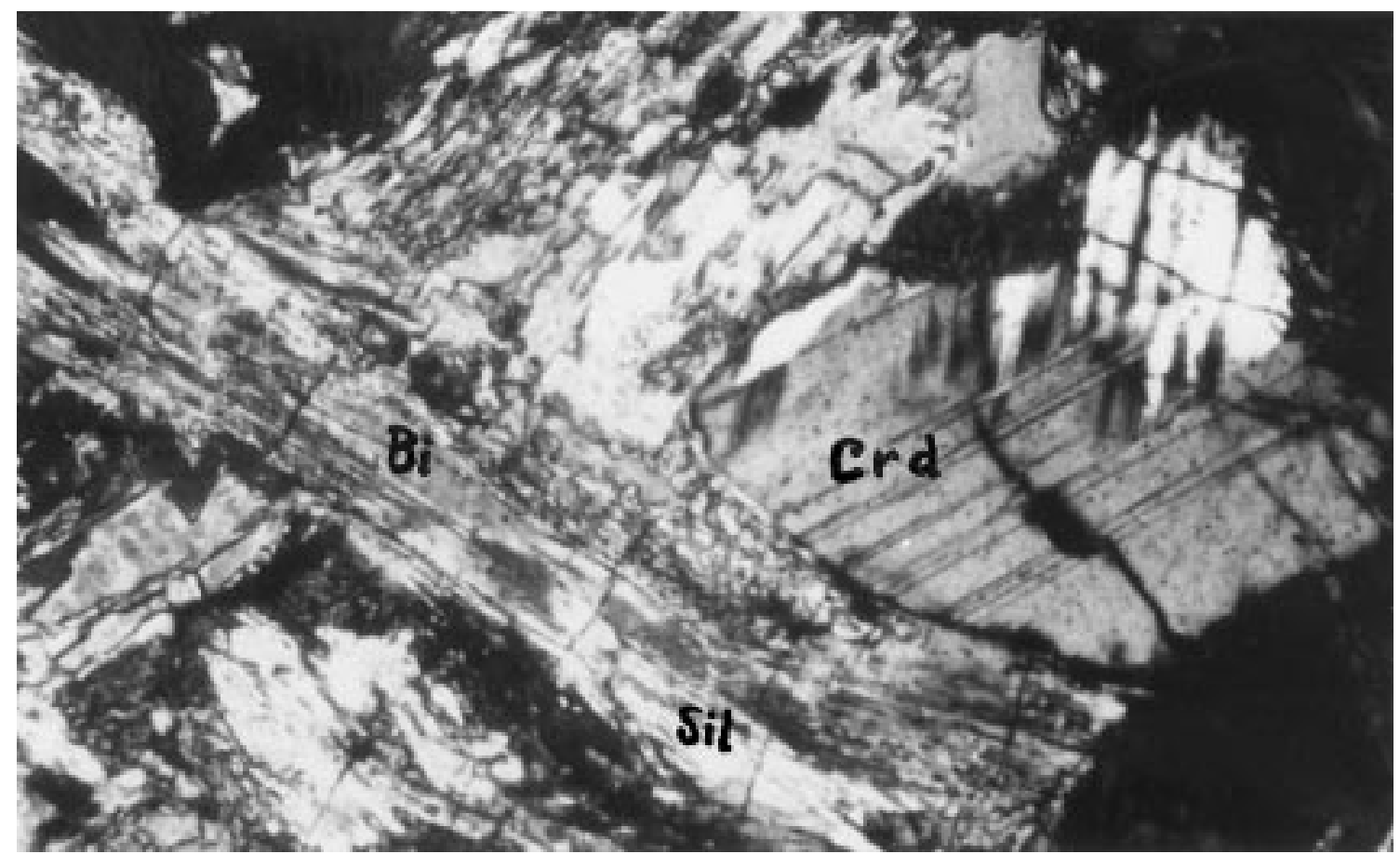

Figure 7. Photomicrograph showing biotite-sillimanite intergrowths bordering cordierite. X:120.

the Eastern Ghats granulite suite, i.e.

orthopyroxene + plagioclase $\rightarrow$ garnet

+ calcic pyroxene + quartz
The second one is an exsolution reaction suggested by the presence of calcic pyroxene lamellae within orthopyroxene grains. Exsolution textures are also displayed by spinels in metapelitic rocks. 


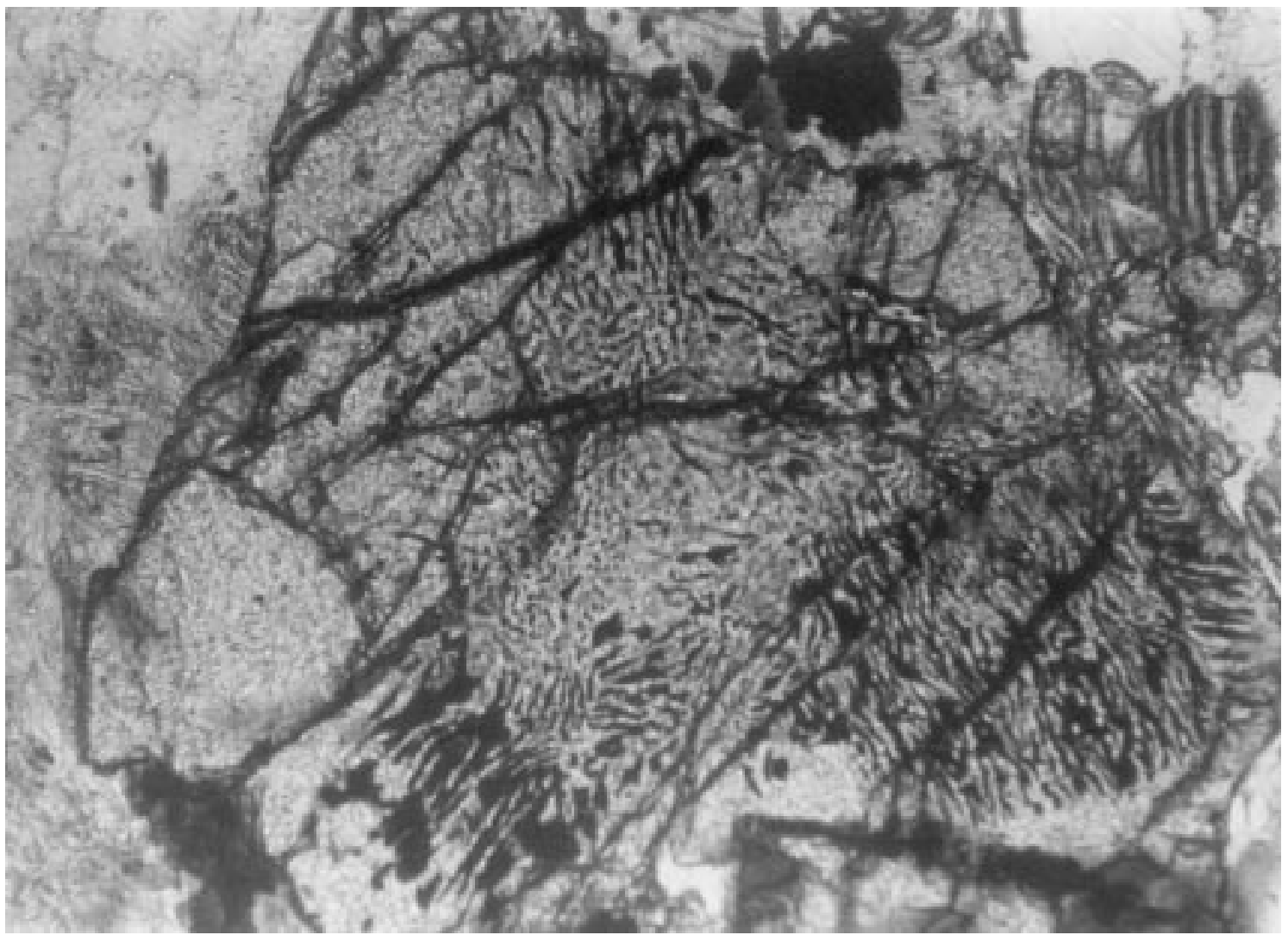

Figure 8. Photomicrograph showing garnet-ilmenite symplectites. X:120.

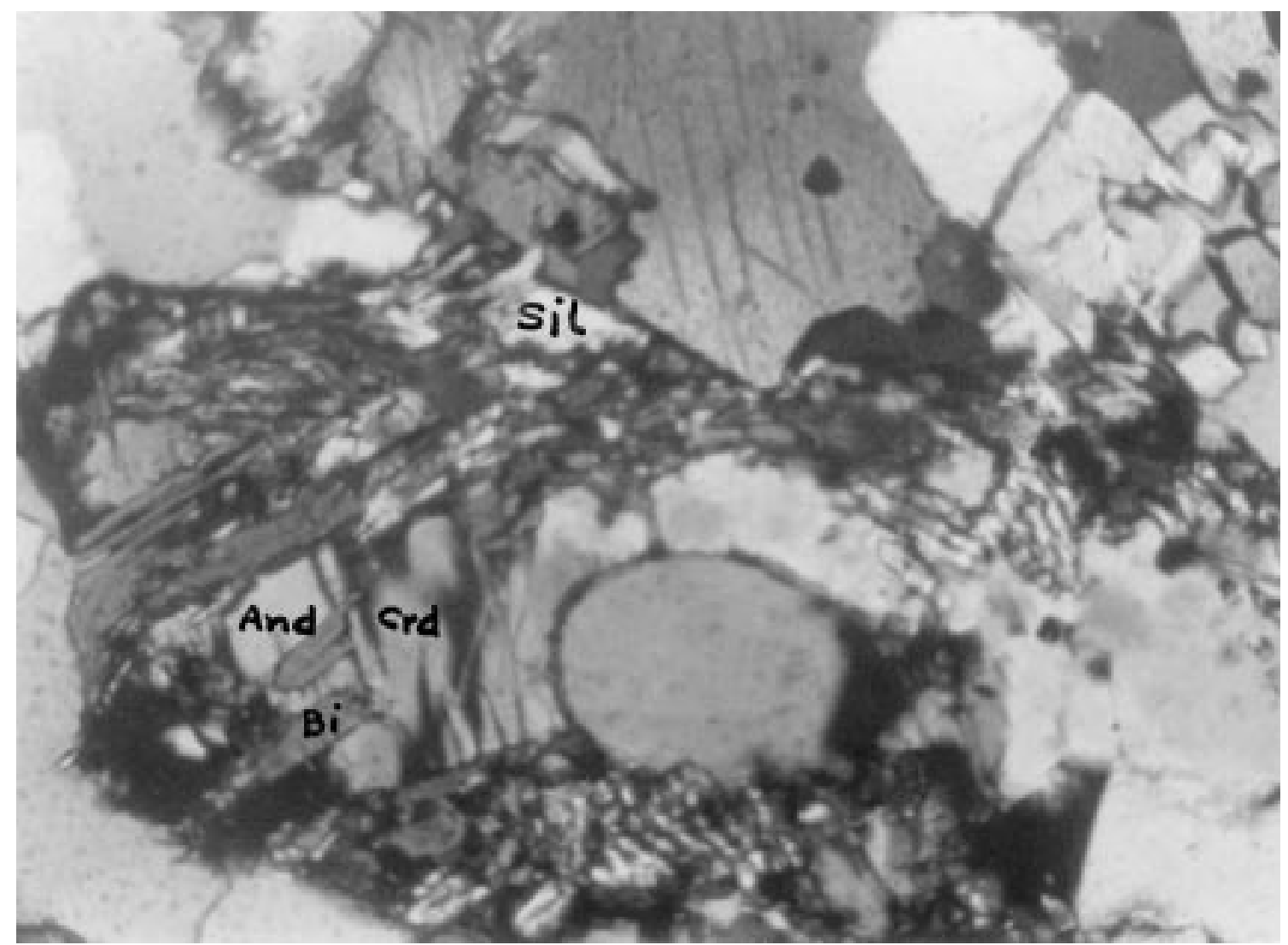

Figure 9. Photomicrograph showing andalusite, probably pseudomorphing sillimanite in a cordierite-granite. X:120. 
The common explanation for reactions (1), (3) and (4) is that they were triggered by cooling. Reactions (1) and (4) can also be driven by increasing pressure for which there is no evidence. Sillimanite to andalusite transformation, because of the negative slope in P-T space, could be caused by decrease of pressure or temperature. Here we argue that cooling was the major control. The exsolution reactions also suggest cooling. The slope of reaction (2) is difficult to estimate, but it is a "retrograde" type reaction that could again indicate cooling.

\section{Rock chemistry}

The results of the chemical analysis of thirtysix rocks chosen from the metapelite suite and granitoids are presented in tables 9 to 11 . In addition, several charnockite-enderbites and basic granulites have also been analysed, and the results will be discussed in a separate communication.

The metapelitic suite, which is often treated as a stratigraphic unit, consists of khondalites (garnetsillimanite gneisses), quartzites and calc-granulites. The dominant variety among these are the khondalites, but rocks intermediate between quartzites and khondalites also occur. Table 9 shows the chemical analyses of three such rocks and of two calc-granulites. The high $\mathrm{Al}_{2} \mathrm{O}_{3}$ and $\mathrm{K}_{2} \mathrm{O}$ contents of the calcgranulites suggest that the parent sedimentary rocks were marly in nature. The khondalites do not show a wide range of variation with respect to major elements. The range of variation of alkalies, and especially of $\mathrm{Na}_{2} \mathrm{O}$ tends to be wider (figure 10, table 9). The $\mathrm{Mg} /$ $(\mathrm{Mg}+\mathrm{Fe})$ ratios have a moderate spread.

Two broad types of granitoids, characterised by the presence or absence of cordierite, are present in the area. Both of these are S-type granites. In normative composition the majority of these rocks correspond to granites and the rest are adamellites or alkali granites, one sample strays into the trondhjemite field (figure 11). Two types of granitoids overlap in Niggli c-al-alk plot (figure 12), but they are well separated in Niggli al-alk-fm (figure 13). Figures 13 and 14 also bring out the major differences between the khondalites and the S-type granites.

Among the cordierite-free granitoids two subgroups can be distinguished. In the field one of them contains layers of cordierite-bearing granites while the other is a homogeneous leptynite. The difference between these two is significant, they can be sharply demarcated in terms of proportions of normative quartz-albiteorthoclase. The variation in the $\mathrm{A} / \mathrm{CNK}$ values, which is a measure of degree of internal differentiation, is as follows. In the leptynites not associated with interlayered cordierite-granite (L-2), these values have a narrow range, 1.11 to 1.24 ; in the leptynite (L-1) which contain layers of cordierite-granite inclusions the values are 0.93 to 1.06 , with one aberrant value of 1.61 caused by very low $\mathrm{Na}_{2} \mathrm{O}$ concentration. In the cordieritegranites the range is wider, namely, 1.13 to 1.59 .

\section{Pressure-temperature record}

The thermometric and barometric estimates from the chemical compositions of mineral pairs and mineral assemblages are presented in table 12 . The pressuretemperature values derived from spinel-cordierite and spinel-garnet sensors are deemed to be less dependable because of uncertainties attaching to activity-composition relations in spinels and of substantial garnite contents of several spinels.

The highest temperatures recorded, $850^{\circ}$ to $900^{\circ} \mathrm{C}$, are from two-pyroxene thermometry in basic granulites (table 12). This could represent igneous temperatures that have been partially reset. The range of temperature obtained from charnockites, metapelites and cordierite-granites is $600^{\circ}$ to $780^{\circ} \mathrm{C}$. Note that the pressure-temperature values from charnockites were derived by the intersection of $\mathrm{Fe}$ - and $\mathrm{Mg}$-versions of GAPQ barometer and garnet-orthopyroxene exchange thermometer. The array of P-T values indicates a cooling, at about $6 \mathrm{kbar}$ pressure, of $700^{\circ}$ to $630^{\circ} \mathrm{C}$ in charnockites and $780^{\circ}$ to $720^{\circ} \mathrm{C}$ in metapelites. There is a suggestion that in metapelites and cordierite-granites the cooling could have proceeded to $680^{\circ} \mathrm{C}$. Another cooling signature at a lower pressure $(5 \mathrm{kbar})$ is evident from the data in table 12. In cordierite-granites cooling from $750^{\circ}$ to $700^{\circ} \mathrm{C}$ is evident, whereas some charnockites could have cooled to approximately $600^{\circ} \mathrm{C}$.

The most outstanding feature of the pressure record is that there is no value above $6.3 \mathrm{kbar}$. This is in sharp contrast to two other areas in the northern Eastern Ghats investigated by the authors (Chilka Lake and Jenapore). Furthermore, it is significant that two sets of pressure values, one around $6 \mathrm{kbar}$ and the other around $5 \mathrm{kbar}$ are registered in three different lithological groups, e.g., charnockites, metapelites and cordierite-granites.

In this connection the pressure value of $12 \mathrm{kbar}$ suggested by Shaw and Arima (1998) appears to be questionable. This pressure was estimated from corundum bearing assemblages, we suggest that corundum is metastable here or derived by later oxidation. Furthermore, the basis of the cooling path derived by Shaw and Arima (1996) can also be questioned. A part of the retrograde path of these authors was derived from the reaction spinel + quartz $\rightarrow$ garnet+sillimanite in the $\mathrm{Mg}$-poor and $\mathrm{Mg}$-rich assemblages. From the details given in their paper it is clear that the Mg-rich assemblages are nothing but cordierite-granites which do not show any evidence in support of this reaction.

The P-T values and some of the mineral reactions relevant to P-T estimation have been plotted in figure 15 . 


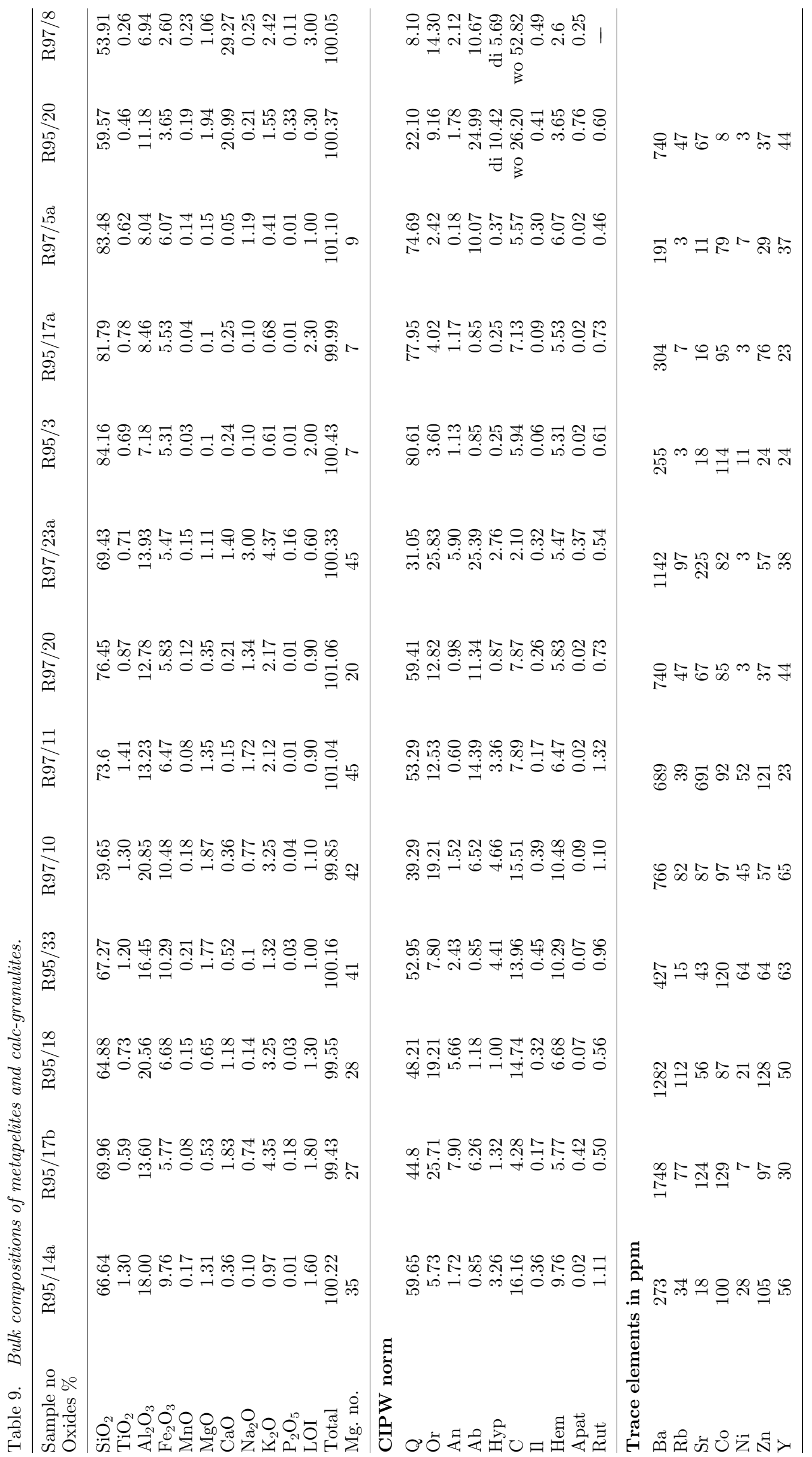




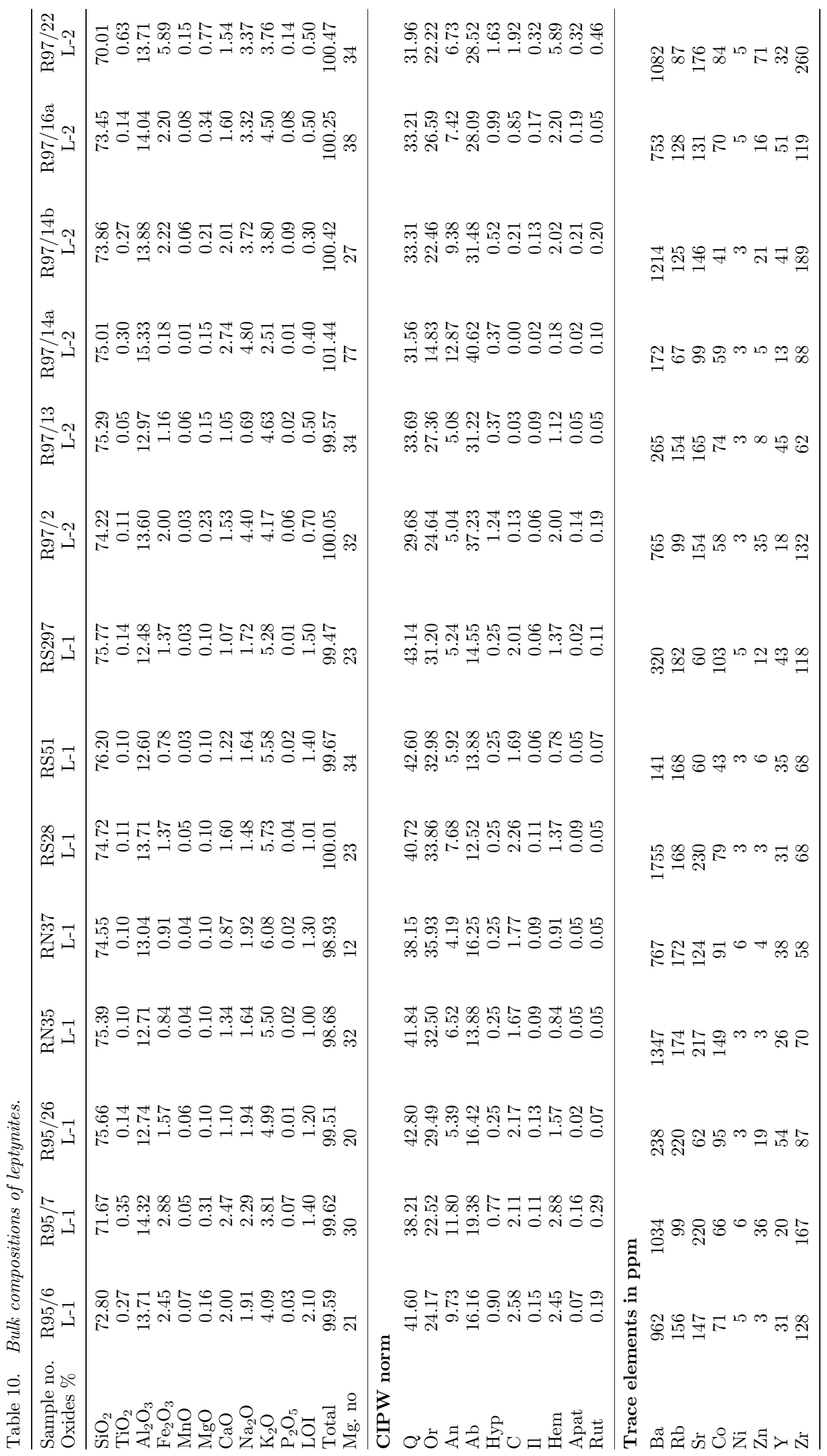


Table 11. Bulk compositions of cordierite-granites.

\begin{tabular}{|c|c|c|c|c|c|c|c|c|}
\hline $\begin{array}{l}\text { Sample no. } \\
\text { Oxides \% }\end{array}$ & $\mathrm{R} 95 / 13$ & $\mathrm{R} 95 / 15 \mathrm{~A}$ & $\mathrm{R} 95 / 16 \mathrm{C}$ & R95/16D & $\mathrm{R} 97 / 5$ & $\mathrm{R} 97 / 21 \mathrm{~B}$ & $\mathrm{R} 97 / 23$ & $\mathrm{R} 97 / 24 \mathrm{~B}$ \\
\hline $\mathrm{SiO}_{2}$ & 69.68 & 61.40 & 69.48 & 68.29 & 74.28 & 68.00 & 69.88 & 70.04 \\
\hline $\mathrm{TiO}_{2}$ & 0.57 & 1.13 & 0.74 & 0.79 & 0.40 & 0.78 & 0.70 & 0.87 \\
\hline $\mathrm{Al}_{2} \mathrm{O}_{3}$ & 14.20 & 16.59 & 14.52 & 14.34 & 13.49 & 14.00 & 13.63 & 14.74 \\
\hline $\mathrm{Fe}_{2} \mathrm{O}_{3}$ & 5.92 & 10.30 & 6.29 & 7.00 & 3.71 & 7.01 & 6.02 & 4.28 \\
\hline $\mathrm{MnO}$ & 0.07 & 0.12 & 0.08 & 0.13 & 0.04 & 0.13 & 0.14 & 0.07 \\
\hline $\mathrm{MgO}$ & 0.16 & 0.56 & 0.41 & 0.63 & 0.60 & 0.90 & 0.83 & 1.40 \\
\hline $\mathrm{CaO}$ & 1.64 & 2.64 & 2.83 & 2.30 & 2.06 & 1.46 & 1.38 & 1.30 \\
\hline $\mathrm{Na}_{2} \mathrm{O}$ & 0.37 & 2.35 & 1.86 & 1.36 & 2.94 & 2.89 & 3.06 & 2.42 \\
\hline $\mathrm{K}_{2} \mathrm{O}$ & 4.91 & 3.56 & 3.16 & 3.85 & 2.62 & 4.41 & 4.19 & 4.66 \\
\hline $\mathrm{P}_{2} \mathrm{O}_{5}$ & 0.17 & 0.17 & 0.07 & 0.19 & 0.10 & 0.14 & 0.12 & 0.01 \\
\hline LOI & 1.90 & 1.20 & 0.20 & 1.20 & 0.80 & 0.60 & 0.60 & 0.80 \\
\hline Total & 99.59 & 100.02 & 99.64 & 100.08 & 101.04 & 100.32 & 100.55 & 100.59 \\
\hline Mg. no & 10 & 18 & 21 & 26 & 39 & 34 & 35 & 57 \\
\hline \multicolumn{9}{|c|}{ CIPW norm } \\
\hline Q & 45.46 & 28.09 & 40.09 & 40.31 & 42.12 & 30.24 & 32.19 & 33.28 \\
\hline Or & 29.02 & 21.04 & 18.67 & 22.75 & 15.48 & 26.06 & 24.76 & 27.54 \\
\hline An & 7.03 & 11.99 & 13.58 & 10.17 & 9.57 & 6.33 & 6.06 & 6.38 \\
\hline $\mathrm{Ab}$ & 3.13 & 19.89 & 15.74 & 11.51 & 24.88 & 24.45 & 25.89 & 20.48 \\
\hline Hyp & 0.40 & 1.39 & 1.02 & 1.57 & 1.49 & 2.24 & 2.07 & 3.49 \\
\hline $\mathrm{C}$ & 5.70 & 4.48 & 3.06 & 4.21 & 2.31 & 2.15 & 1.84 & 3.38 \\
\hline Il & 0.15 & 0.26 & 0.17 & 0.28 & 0.09 & 0.28 & 0.30 & 0.15 \\
\hline Hem & 5.92 & 10.30 & 6.29 & 7.00 & 3.71 & 7.01 & 6.02 & 4.28 \\
\hline Apat & 0.39 & 0.39 & 0.16 & 0.44 & 0.23 & 0.32 & 0.28 & 0.02 \\
\hline Rut & 0.49 & 0.99 & 0.65 & 0.64 & 0.35 & 0.63 & 0.54 & 0.79 \\
\hline \multicolumn{9}{|c|}{ Trace elements in ppm } \\
\hline $\mathrm{Ba}$ & 1428 & 1045 & 1003 & 1167 & 1206 & 1250 & 993 & 1417 \\
\hline $\mathrm{Rb}$ & 171 & 95 & 66 & 100 & 61 & 113 & 99 & 120 \\
\hline $\mathrm{Sr}$ & 98 & 173 & 170 & 155 & 142 & 144 & 183 & 168 \\
\hline Co & 3 & 87 & 118 & 106 & 91 & 76 & 94 & 75 \\
\hline $\mathrm{Ni}$ & 9 & 16 & 16 & 9 & 3 & 11 & 3 & 17 \\
\hline Zn & 125 & 150 & 87 & 91 & 141 & 111 & 85 & 68 \\
\hline Y & 27 & 34 & 17 & 16 & 17 & 36 & 41 & 18 \\
\hline $\mathrm{Zr}$ & 383 & 392 & 281 & 307 & 235 & 302 & 263 & 168 \\
\hline
\end{tabular}

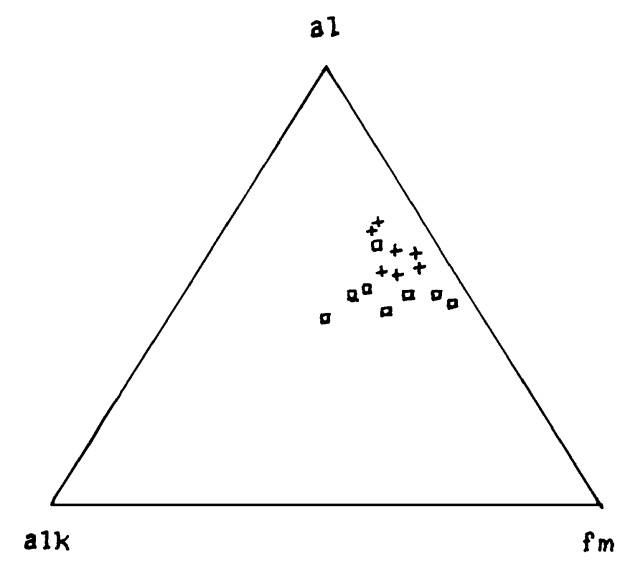

Figure 10. Comparative al-alk-fm plots for Rayagada metapelites (squares) and group-A metapelites of Chilka Lake (crosses).

\section{Discussion}

From the viewpoint of the major issues of this paper a convenient starting point is a comparison with the other investigated areas of the northern Eastern Ghats.

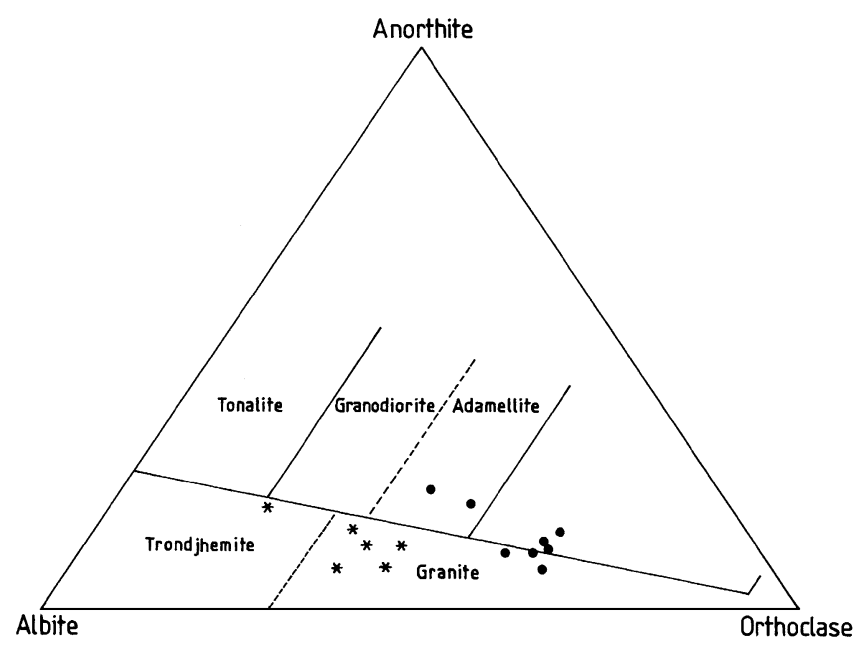

Figure 11. Normative plots of granitoids. L-1 leptynites (interlayered with cordierite-granites) denoted by solid dots, L-2 by asterisks.

There is a broad similarity in the lithological spread (charnockite-khondalite-granitoid trinity), and a commonality in the structural set up. Neither is there any structural or geochemical evidence which suggests 


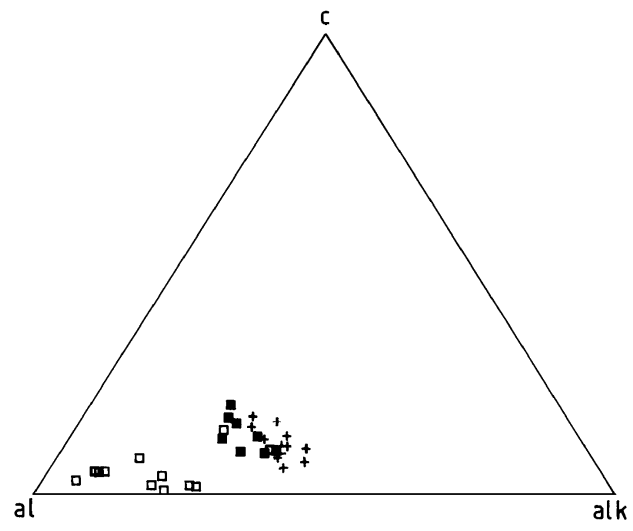

Figure 12. c-alk plots for Rayagada khondalites (squares), cordierite-granites (filled squares) and leptynites (crosses).

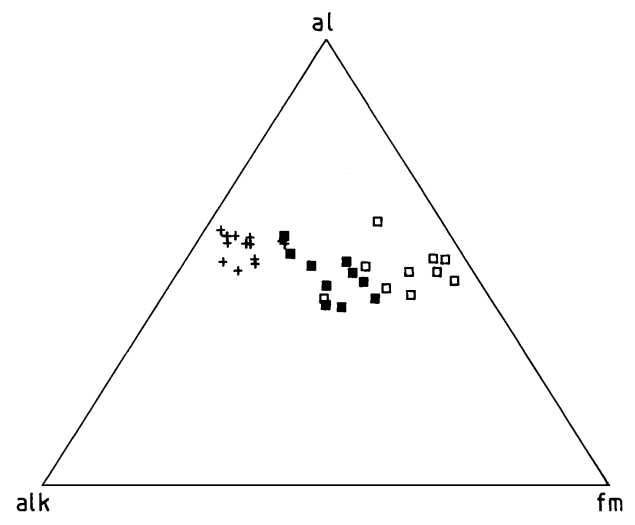

Figure 13. al-alk-fm plots for Rayagada granitoids and khondalites; symbols as in figure 12 . assembly of diverse terrains. Thus it is necessary as well as instructive to consider the findings on the Rayagada rocks against those on the Chilka Lake and Jenapore rocks.

The Chilka Lake and Jenapore granulites record a high temperature and moderately high pressure values: $1000^{\circ} \mathrm{C}, 9 \mathrm{kbar}$ and $950^{\circ} \mathrm{C}, 9.5 \mathrm{kbar}$ respectively (Sen et al 1995; Kar et al 2000). In the Chilka Lake area this high $\mathrm{P}-\mathrm{T}$ record is retrieved from $\mathrm{Mg}-\mathrm{Al}-$ rich granulites of broadly metapelitic composition, a variety not present in Rayagada. In Jenapore the peak P-T values are retrieved from mafic granulites and massiftype charnockites. It is important to note that in both these areas this high temperature metamorphism corresponds to $F_{1}$ folding. In Rayagada the effects of $F_{1}$ folding appear to have been largely erased. Again, the cooling at $\sim 8 \mathrm{kbar}$ pressure registered in both Chilka Lake and Jenapore rocks has no counterpart in the Rayagada granulites.

The maximum pressure registered by the Rayagada rocks is $6.3 \mathrm{kbar}$, this corresponds to the syn- $F_{2}$ tectonothermal event. Similar pressures, broadly corresponding to $F_{2}$ have been recorded both at Chilka and Jenapore. The major petrological response in all three areas was melting in metapelitic rocks, producing leptynites. In Rayagada the close association of the leptynites and khondalites and the presence of sillimanite inclusions in several garnets of leptynites indicate that the granitoids were derived by partial melting of metapelites (cf. Sen and Bhattacharya 1997). Additionally, there is a prominent record of cooling at $6 \mathrm{kbar}$ in Rayagada as well as Chilka. The record is similar in Jenapore (Kar et al 2000).

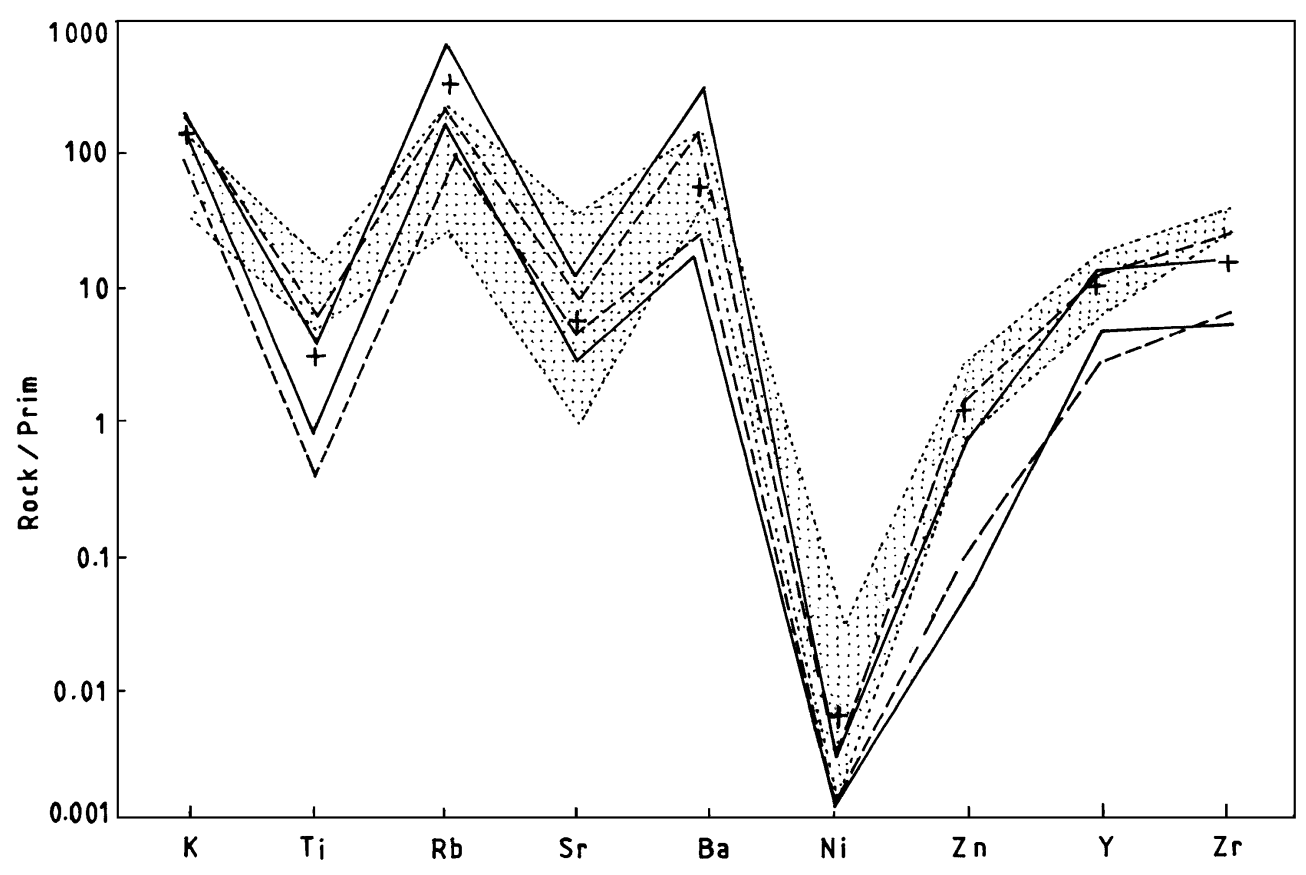

Figure 14. Multi-element plots for khondalites and granitoids of Rayagada. Envelopes for khondalites - stippled; for L-1 enclosed within bold lines; for L-2 - enclosed within dashed lines. Concentrations for average S-type granites (Chappell and White 1992) denoted by crosses. 
Table 12. Pressure-Temperature estimates from Rayagada.

\begin{tabular}{|c|c|c|c|c|c|}
\hline \multicolumn{6}{|l|}{ Mineral assemblage } \\
\hline Grt-Sil-Il-Ru-Q & $95 / 18$ & $\underline{\mathrm{S}-22}$ & & & \\
\hline$($ Berman, 1991)* & $\begin{array}{c}\overline{6 \mathrm{kbar}} \\
\left(800^{\circ} \mathrm{C}\right)\end{array}$ & $\begin{array}{l}5.2 \mathrm{kbar} \\
\left(800^{\circ} \mathrm{C}\right)\end{array}$ & & & \\
\hline Grt-Sil-Plag-Q & $97 / 21 b$ & $97 / 24 b$ & & & \\
\hline (Berman, 1991)* & $\begin{array}{l}\overline{5 \mathrm{kbar}} \\
\left(700^{\circ} \mathrm{C}\right)\end{array}$ & $\begin{array}{l}\overline{5 \mathrm{kbar}} \\
\left(700^{\circ} \mathrm{C}\right)\end{array}$ & & & \\
\hline \multirow[t]{2}{*}{ Il-Mgt (Powell \& Powell 1977)* } & $95 / 18$ & $95 / 18$ & $95 / 15 \mathrm{a}$ & $95 / 15 \mathrm{a}$ & $\underline{\mathrm{S}-22}$ \\
\hline & $\overline{780^{\circ} \mathrm{C}}$ & $\overline{720^{\circ} \mathrm{C}}$ & $\overline{700^{\circ} \mathrm{C}}$ & $\overline{680^{\circ} \mathrm{C}}$ & $690^{\circ} \mathrm{C}$ \\
\hline \multirow[t]{2}{*}{ Spl-Crd (Perchuk \& Gerya 1989)* } & $95 / 17 \mathrm{~b}$ & $95 / 34$ & & & \\
\hline & $\begin{array}{l}\overline{700^{\circ} \mathrm{C},} \\
(6 \mathrm{~kb})\end{array}$ & $\begin{array}{c}\overline{650^{\circ} \mathrm{C}}, \\
(6 \mathrm{~kb})\end{array}$ & & & \\
\hline Grt-Spl & $95 / 15 \mathrm{a}$ & $95 / 4$ & & & \\
\hline (Perchuk \& Gerya 1989)* & $\begin{array}{c}\overline{550^{\circ} \mathrm{C}}, \\
(6 \mathrm{~kb})\end{array}$ & $\begin{array}{l}5 \overline{60^{\circ} \mathrm{C}}, \\
(6 \mathrm{~kb})\end{array}$ & & & \\
\hline Grt-Crd & $\underline{\mathrm{S}-18}$ & $95 / 16 \mathrm{c}$ & $97 / 24 b$ & & \\
\hline$($ Berman 1991)* & $\begin{array}{l}750^{\circ} \mathrm{C} \\
(5 \mathrm{~kb})\end{array}$ & $\begin{array}{l}\overline{700^{\circ} \mathrm{C}} \\
(5 \mathrm{~kb})\end{array}$ & $\begin{array}{c}\overline{700^{\circ} \mathrm{C}} \\
(5 \mathrm{~kb})\end{array}$ & & \\
\hline Grt-Opx-Plag-Q & $97 / 3$ (core) & $97 / 3(\mathrm{rim})$ & $97 / 14 c$ (core) & $97 / 14 \mathrm{c}(\mathrm{rim})$ & \\
\hline$($ Berman 1991)* & $\begin{array}{l}700^{\circ} \mathrm{C} \\
6.3 \mathrm{kbar}\end{array}$ & $\begin{array}{l}630^{\circ} \mathrm{C}, \\
5.8 \mathrm{kbar}\end{array}$ & $\begin{array}{l}610^{\circ} \mathrm{C} \\
5 \mathrm{kbar}\end{array}$ & $\begin{array}{c}590^{\circ} \mathrm{C} \\
4.7 \mathrm{kbar}\end{array}$ & \\
\hline $\mathrm{Fe}-\mathrm{Mg}-\mathrm{Ca}$ & $97 / 17 \mathrm{~B}$ & $\underline{\mathrm{RN}} 73$ & & & \\
\hline $\begin{array}{l}\text { Pyroxenes } \\
\text { (Berman 1991)* }\end{array}$ & $\overline{850^{\circ} \mathrm{C}}$ & $900^{\circ} \mathrm{C}$ & & & \\
\hline
\end{tabular}

* Geothermometric and geobarometric methods adopted

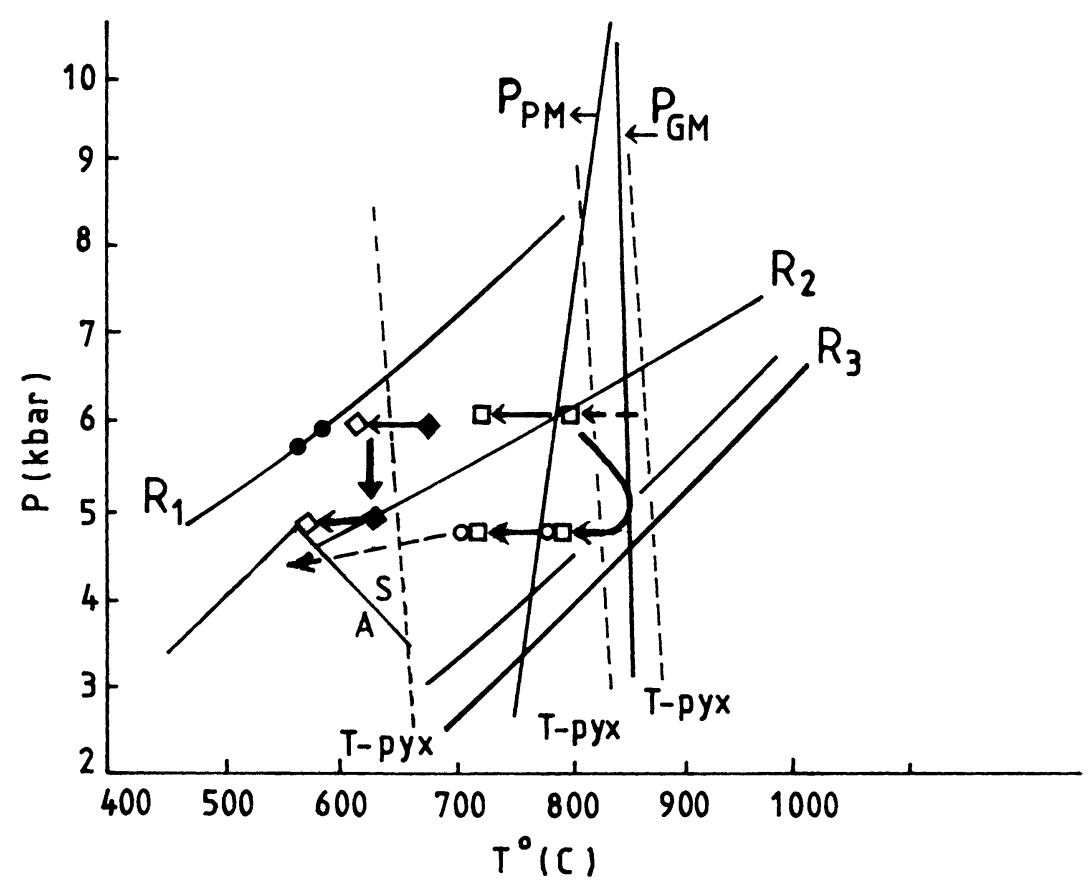

Figure 15. Pressure-temperature diagram for the Rayagada rocks. $R_{1}, R_{2}$ and $R_{3}$ (2 samples) represent computed geobarometric equations corresponding to reactions 1, GRAIL and GASP respectively. The three dotted lines marked T-pyx denote temperatures from two-pyroxene thermometry in basic granulites. $\mathrm{P}_{\mathrm{PM}}$ and $\mathrm{P}_{\mathrm{GM}}$ are melting curves for pelites and graywackes taken from Stevens et al (1997). P-T values derived from analysed samples: open circles (garnet-cordierite), open squares (ilmenitemagnetite), solid circles (garnet-spinel), solid diamonds (core temperatures from orthopyroxene-garnet), open diamonds (rim temperatures from orthopyroxene-garnet). Arrows represent the projected cooling paths at 6 and 5 kbar. Stability fields for $\mathrm{Al}_{2} \mathrm{O}_{5}$ polymorphs, after Holland and Powell (1990). 
Table 13. Two way analysis of variance (ANOVA).

\begin{tabular}{|c|c|c|c|c|}
\hline Source of variation & Sum of squares & Degrees of freedom & Mean squares & F-Tests \\
\hline Among Samples & 0.12 & 7 & 0.017 & 0.0366 \\
\hline $\begin{array}{l}\text { Leptynites- } 1 \\
\text { Among treatments } \\
\text { Error } \\
\text { Total variation }\end{array}$ & $\begin{array}{r}38999.02 \\
32.53 \\
39031.67\end{array}$ & $\begin{array}{l}10 \\
70 \\
87\end{array}$ & $\begin{array}{r}3899.02 \\
0.465\end{array}$ & \\
\hline Among Samples & 1.40 & 5 & 0.279 & 0.2573 \\
\hline $\begin{array}{l}\text { Leptynites- } 2 \\
\text { Among treatments } \\
\text { Error } \\
\text { Total variation } \\
\end{array}$ & $\begin{array}{r}28453.22 \\
54.24 \\
28508.86 \\
\end{array}$ & $\begin{array}{l}10 \\
50 \\
65 \\
\end{array}$ & $\begin{array}{r}2845.323 \\
1.085\end{array}$ & \\
\hline Among Samples & 0.23 & 7 & 0.033 & 0.0072 \\
\hline $\begin{array}{l}\text { Khondalites } \\
\text { Among treatments } \\
\text { Error } \\
\text { Total variation }\end{array}$ & $\begin{array}{r}32874.63 \\
323.69 \\
33198.55\end{array}$ & $\begin{array}{l}10 \\
70 \\
87\end{array}$ & $\begin{array}{r}3287.462 \\
4.624\end{array}$ & \\
\hline Among Samples & 0.17 & 8 & 0.021 & 0.0095 \\
\hline $\begin{array}{l}\text { Cordierite-granite } \\
\text { Among treatment } \\
\text { Error } \\
\text { Total variation }\end{array}$ & $\begin{array}{r}37623.80 \\
180.69 \\
37804.67\end{array}$ & $\begin{array}{l}10 \\
80 \\
98\end{array}$ & $\begin{array}{r}3762.38 \\
2.259\end{array}$ & \\
\hline
\end{tabular}

Table 14. Computations relevant to mixing of khondalites and granitoids.

\begin{tabular}{|c|c|c|c|c|c|c|c|c|}
\hline Oxides & $\begin{array}{c}\text { Khondalites } \\
\text { Mean (8) }\end{array}$ & S.D & $\begin{array}{c}\text { Leptynites (L1) } \\
\text { Mean (8) }\end{array}$ & S.D. & $\begin{array}{c}\text { Leptynites (L2) } \\
\text { Mean (6) }\end{array}$ & S.D. & $\begin{array}{c}\text { Cordierite-granite } \\
\text { Mean (9) }\end{array}$ & S.D. \\
\hline $\mathrm{SiO}_{2}$ & 68.49 & 4.86 & 74.59 & 1.48 & 73.64 & 1.74 & 69.47 & 3.56 \\
\hline $\mathrm{TiO}_{2}$ & 1.01 & 0.30 & 0.16 & 0.09 & 0.25 & 0.19 & 0.72 & 0.21 \\
\hline $\mathrm{Al}_{2} \mathrm{O}_{3}$ & 16.18 & 3.09 & 13.16 & 0.62 & 13.92 & 0.71 & 14.37 & 0.87 \\
\hline $\mathrm{Fe}_{2} \mathrm{O}_{3}$ & 7.59 & 2.04 & 1.52 & 0.72 & 2.28 & 1.77 & 5.90 & 2.12 \\
\hline $\mathrm{MnO}$ & 0.14 & 0.04 & 0.05 & 0.01 & 0.07 & 0.04 & 0.09 & 0.04 \\
\hline $\mathrm{MgO}$ & 1.12 & 0.53 & 0.13 & 0.07 & 0.31 & 0.21 & 0.62 & 0.37 \\
\hline $\mathrm{CaO}$ & 0.75 & 0.59 & 1.46 & 0.50 & 1.75 & 0.52 & 1.87 & 0.57 \\
\hline $\mathrm{Na}_{2} \mathrm{O}$ & 0.99 & 0.94 & 1.82 & 0.23 & 3.38 & 1.31 & 2.03 & 0.89 \\
\hline $\mathrm{K}_{2} \mathrm{O}$ & 2.73 & 1.20 & 5.13 & 0.75 & 3.89 & 0.70 & 4.04 & 0.77 \\
\hline $\mathrm{P}_{2} \mathrm{O}_{5}$ & 0.06 & 0.06 & 0.03 & 0.02 & 0.07 & 0.04 & 0.13 & 0.06 \\
\hline LOI & 1.15 & 0.37 & 1.38 & 0.31 & 0.48 & 0.12 & 0.94 & 0.46 \\
\hline
\end{tabular}

\begin{tabular}{|c|c|c|c|c|c|c|c|}
\hline \multirow[b]{2}{*}{ Oxides } & \multirow[b]{2}{*}{$\begin{array}{c}\text { Alternative } 1 \\
80 \% \text { L1 } \\
+20 \% \text { crd- } \\
\text { granite }\end{array}$} & \multirow[b]{2}{*}{$\begin{array}{c}\text { Alternative } 2 \\
85 \% \text { L1 } \\
+15 \% \text { crd- } \\
\text { granite }\end{array}$} & \multirow[b]{2}{*}{$\begin{array}{c}\text { Leptynites-2 } \\
\text { Mean }\end{array}$} & \multicolumn{2}{|c|}{ Computed Protoliths } & \multicolumn{2}{|c|}{ Experimental Protoliths } \\
\hline & & & & $\begin{array}{c}60 \% \\
\text { Khondalites } \\
+40 \% \text { L2 }\end{array}$ & $\begin{array}{c}70 \% \\
\text { Khondalite } \\
+30 \% \text { L2 }\end{array}$ & $\begin{array}{l}\text { Holz \& } \\
\text { Johannes, } \\
\quad 1991\end{array}$ & $\begin{array}{l}\text { NBS, Stevens } \\
\text { et al., } 1997\end{array}$ \\
\hline $\mathrm{SiO}_{2}$ & 73.56 & 73.82 & 73.64 & 70.55 & 70.03 & 65.87 & 58.15 \\
\hline $\mathrm{TiO}_{2}$ & 0.27 & 0.24 & 0.25 & 0.71 & 0.79 & 0.65 & 0.63 \\
\hline $\mathrm{Al}_{2} \mathrm{O}_{3}$ & 13.40 & 13.34 & 13.92 & 15.28 & 15.51 & 15.82 & 27.67 \\
\hline $\mathrm{Fe}_{2} \mathrm{O}_{3}$ & 2.40 & 2.18 & 2.28 & 5.46 & 5.99 & $4.51 * \mathrm{FeO}$ & $4.92 * \mathrm{FeO}$ \\
\hline $\mathrm{MnO}$ & 0.06 & 0.05 & 0.07 & 0.11 & 0.12 & & 0.01 \\
\hline $\mathrm{MgO}$ & 0.23 & 0.20 & 0.31 & 0.79 & 0.87 & 1.60 & 3.61 \\
\hline $\mathrm{CaO}$ & 1.54 & 1.52 & 1.75 & 1.15 & 1.06 & 1.46 & 0.86 \\
\hline $\mathrm{Na}_{2} \mathrm{O}$ & 1.86 & 1.85 & 3.38 & 1.94 & 1.70 & 3.08 & 0.86 \\
\hline $\mathrm{K}_{2} \mathrm{O}$ & 4.91 & 4.97 & 3.89 & 3.20 & 3.08 & 3.95 & 2.51 \\
\hline $\mathrm{P}_{2} \mathrm{O}_{5}$ & 0.05 & 0.05 & 0.07 & 0.07 & 0.06 & & \\
\hline LOI & 1.29 & 1.31 & 0.48 & 0.88 & 0.95 & & $0.80 \mathrm{H}_{2} \mathrm{O}$ \\
\hline
\end{tabular}

The melting of metapelitic rocks at Rayagada is distinct in style when compared with the other areas, and provides clues for reconstructing the petrologicalcum-tectonic evolution of the Rayagada granulites.
First, there are two kinds of granitoids, distinguished by the presence or absence of cordierite, both of which are S-type granites. Second, the cordierite-granites are interlayered with leptynites (L-1) which are of a 
different composition than the leptynites (L-2) free of such interlayering. Third, the relative volumes of this cordierite-granite are around 15 to $20 \%$ of the total L-1 + cordierite-granite exposures. When we compare the metapelite-granitoid complex of the Chilka Lake area with the present ones several significant similarities and differences emerge (Sen and Bhattacharya 1997). The most abundant variety among the khondalite suite at Chilka Lake, the group-A khondalites, are quite comparable with the metapelites of Rayagada (figure 10). The other metapelites of Chilka, barring the $\mathrm{Mg}-\mathrm{Al}$ rich ones, are distinctly migmatitic and contain cordierite. In contrast, the cordierite granites of Rayagada are homogeneous with sharp boundaries which separate them from the host leptynites. The presence of migmatites, the minor extent of melting and near isothermal decompression at Chilka can be explained in terms of relatively slow tectonic uplift rates (less than $0.5 \mathrm{~mm} /$ year). This is compatible with the suggestion of Patino Douce et al (1990) that migmatites are syntectonic, while granite plutonism is commonly post-tectonic or related to exhumation.

For understanding the origin of the two varieties of granitoids, the possibility of the presence of two different metapelitic protoliths should be evaluated. The compositional spread of the Rayagada metapelites is rather narrow; additionally, composition of the sensitive mineral phases such as garnets are also similar. It is evident from the statistical parameters presented in table 13 that the restitic metapelites have a low variance, and hence it is reasonable to consider the metapelitic protolith of Rayagada as a single variety.

Derivation of the two types of granites from protoliths of similar composition could only mean melting under different conditions. Figure 15 shows that a melting curve valid for metapelitic protolith could be intersected at about $6 \mathrm{kbar}$ and $780^{\circ} \mathrm{C}$. A further melting is possible at $5 \mathrm{kbar}, 830^{\circ} \mathrm{C}$ for a greywackelike composition. It is significant that the cordieritegranites show a near isobaric cooling path starting from 5 kbar. We envision a two stage melting where the second melting took place at shallower depths during exhumation. The second melting is inferred to have taken place at pressures lower by one kbar and temperatures higher by $50^{\circ} \mathrm{C}$ approximately. This implies a tectonic uplift at rates greater than $0.5 \mathrm{~mm} /$ year as shown by our unpublished calculations. Furthermore, the melting reaction curve that is intersected at $5 \mathrm{kbar}$ is valid for graywackes, implying that after the first stage of melting the restites had approached the composition of graywacke. The compositional field of (L-2) leptynites indicates that if melts of such composition are extracted, the residual rocks would move in the direction of graywackes.

It is known from recent experimental investigations on melting of pelitic compositions that cordierite along with other phases are produced by melting at lower pressures, and cordierite is eliminated at higher pressures. This general trend can be read from the experimental results of Carrington and Harley (1995b) and Stevens et al (1997). It must however be admitted that the starting compositions selected in these experiments, especially in Stevens et al (1997) have very high $\mathrm{Al}_{2} \mathrm{O}_{3}$ contents. Among the starting materials reported by Stevens et al (1997) the NBS pelite is the closest to the probable protolith composition at Rayagada; even then the alumina is fairly high in the NBS pelite. Such high alumina might have caused extended stability of cordierite in these experiments.

In other words, we suggest that in the first melting at $6 \mathrm{kbar}$ cordierite was not produced because of composition and/or pressure, whereas both these factors favoured cordierite as a peritectic phase during melting around $5 \mathrm{kbar}$. A clue to the compositional change of the protolith between two phases of melting is the difference in the $\mathrm{Rb} / \mathrm{Sr}$ ratios of the leptynites L- 1 and $\mathrm{L}-2$. The former has an average $\mathrm{Rb} / \mathrm{Sr}$ of $1.72 \pm 0.45$ while in the latter the average is $0.77 \pm 0.17$. An examination of partition coefficients between minerals and peraluminous granitic melts (Harris et al 1995) shows that among the four relevant minerals, alkali feldspar, muscovite, biotite and plagioclase, biotite has a very high $\mathrm{Rb} / \mathrm{Sr}$ ratio with respect to melts, e.g. 6.2 (alkali feldspar-0.25, muscovite-0.5, plagioclase-0.01). Biotite dehydration melting has taken place at both pressures and the biotite left after melting at $6 \mathrm{kbar}$ would be considerably enriched in $\mathrm{Rb} / \mathrm{Sr}$, thereby producing a higher value in L-1. The very low values of plagioclase will have an opposite effect, but this will be minor, because in the second melting biotite could have melted out completely whereas plagioclase would be a peritectic phase.

We envisage that during the second melting at 5 kbar granitoids of L-1 were produced along with cordierite-garnet-plagioclase-sillimanite-quartz and alkali feldspar as peritectic phases. These phases separated out to form the cordierite-granite layers. This implies that L- 1 plus 15 to $20 \%$ of cordieritegranite should approximate the composition of L-2. That such chemical equivalence is within the realm of possibility is borne out by the calculations shown in table 14. The derived and real values of L-2 are quite close, excepting $\mathrm{Na}_{2} \mathrm{O}$; in the computed composition $\mathrm{Na}_{2} \mathrm{O}$ is lower. This is evidently caused by a large spread, with respect to $\mathrm{Na}_{2} \mathrm{O}$, in the cordierite-granites.

Proceeding along these lines, it is possible to reconstruct the composition of the protolith by assuming reasonable degrees of melting. In table 14, we have combined in 30:70 and 40:60 proportions of L-2 and the average restites. It is interesting that this hypothetical protolith is quite close in composition to the starting material in the experiments of Holtz and Johannes (1991). The alumina contents are more realistic than its counterparts in the other experiments quoted here, the $\mathrm{Mg} / \mathrm{Fe}$ ratios are also moderate. 
Holtz and Johannes (1991) conducted their experiments at 3 and $5 \mathrm{kbar}$ and in both sets cordierite was a peritectic phase. No experiments were, however, carried out at higher pressures.

Thus the integrated history of granulites and granites of Rayagada is distinctly at variance with that of the two other granulite terrains in the northern Eastern Ghats. There are several significant differences. Two stage melting producing different granitoids, signatures of cooling rather than decompression in the later stages and virtual erasure of the effects of early deformation and metamorphism are the three areas of major divergence. These differences will have to be accounted for in reconstructing the evolution of at least the northern part of the Eastern Ghats.

\section{Concluding remarks}

In sum, the main causative factor behind the diverse scenario of evolution of Rayagada granulites appears to be the last melting caused by exhumation at tectonic rates. The last stages of Chilka granulites were marked by isothermal decompression accompanied by a minor amount of melting (leucosomes in $S_{3}$ fractures). In Rayagada the second melting at low pressure not only replaced the effects of decompression with those of melting, but also erased a part of the early $F_{1}$ history. It is noteworthy that sillimanite to andalusite transformation, the breakdown reaction of cordierite and spinel + quartz $\rightarrow$ garnet + sillimanite reaction, all testify to an all pervasive cooling at about $5 \mathrm{kbar}$ pressure.

For the first melting at $6 \mathrm{kbar}$, which again could have obliterated the effects of earlier deformation and metamorphism, a prograde increase of temperature was the likely cause. There is no direct evidence for prograde reactions corresponding to this pressure at Rayagada, but in Jenapore a prograde P-T path at 6 to $7 \mathrm{kbar}$ and $630^{\circ}$ to $750^{\circ} \mathrm{C}$ was invoked during $F_{2}$ deformation by Kar et al (2000). The possibility of such a P-T path was also suggested for the Chilka Lake granulites by Sen et al (1995).

Thus it seems plausible that the nature and sequence of tectonic-metamorphic events were the same across the three terrains in the northern Eastern Ghats, but different rates of exhumation and the different styles of melting produced different signatures in the Rayagada granulite terrane.

\section{Acknowledgement}

Chemical analyses of rocks were performed at the XRF laboratory, USIC-SIF, Gauhati University. Minerals were analysed in the EPMA laboratory, USIC, Roorkee University. This work was supported by the Indian National Science Academy, New Delhi and Indian Statistical Institute, Calcutta. The help of all these institutions is gratefully acknowledged.

\section{References}

Berman R G 1991 Thermobarometry using multi-equilibrium calculations: a new technique, with petrological applications; Canadian Mineral. 29 833-856

Bhattacharya S, Sen S K and Acharyya A 1994 Structural setting of the Chilka Lake granulite-migmatite-anorthosite suite with emphasis on the time relation of charnockites; Precambrian Research 66 393-409

Bhattacharya S 1997 Evolution of Eastern Ghats granulite belt in a compressional tectonic regime and juxtaposition against the Iron Ore craton of Singhbhum by oblique collision-transpression; Proc. Indian Acad. Sci. (Earth Planet. Sci.) 106 65-75

Carrington D P and Harley S L 1995a The stability of osumilite in metapelitic granulites; J. Met. Geol. 13 613-625

Carrington D P and Harley S L 1995b Partial melting and phase relations in high grade metapelites: an experimental petrogenetic grid in the KFMASH system; Contrib. Mineral. Petrol. 120 270-291

Chappell B W and White A J R 1992 I- and S-type granites in the Lachlan fold belt. Trans. Royal Soc. Edinburgh; Earth Sci. 83 1-26

Dasgupta S, Sanyal S, Sengupta P and Fukuoka M 1994 Petrology of granulites from Anakapalle: evidence for Proterozoic decompression in the Eastern Ghats, India; J. Petrol. 35 433-459

Harris N, Ayres M and Massey J 1995 Geochemistry of granitic melts produced during incongruent melting of muscovite; Implications for the extraction of Himalayan leucogranite magmas; J. Geophys. Res. 100 15767-15777

Holland T J B and Powell R 1990 An enlarged and updated internally consistent thermodynamic dataset with uncertainties and correlations: the system $\mathrm{K}_{2} \mathrm{O}-\mathrm{Na}_{2} \mathrm{O}-\mathrm{CaO}-\mathrm{MgO}-$ $\mathrm{MnO}-\mathrm{FeO}-\mathrm{Fe}_{2} \mathrm{O}_{3}-\mathrm{Al}_{2} \mathrm{O}_{3}-\mathrm{TiO}_{2}-\mathrm{SiO}_{2}-\mathrm{C}-\mathrm{H}_{2}-\mathrm{O}_{2} ;$ J. Metamorphic Geology 8 89-124

Holtz F and Johannes W 1991. Genesis of peraluminous granites. I. Experimental investigation of melt compositions at 3 and 5 kbar and various $\mathrm{H}_{2} \mathrm{O}$ activities; J. Petrol. 32 935-958

Kar R, Bhattacharya S and Sheraton J W 2000 Hornblendedehydration melting in mafic rocks and the link between massif-type Charnockite and associated granulites: Eastern ghats Granulite Belt, India; J. Petrol. (communicated)

Olsen E and Bunch T E 1970 Compositions of natural osumilites; American Mineral. 55 875-879

Patino Douce A E, Humphreys E D and Johnston A D 1990 Anatexis and metamorphism in tectonically thickened continental crust exemplified by the Sevier hinterland, western North America; Earth Planet. Sci. Lett. 97 290-315

Perchuk L and Gerya T 1989 Petrology and retrograde P-T path in granulites of the Kanskaya formation, Yenisey range, Eastern Siberia; J. Metamorphic Geology 7 599-617

Pereira M D and Bea F 1994 Cordierite-producing reactions in the Pena Negra Complex, Avila Batholith, Central Spain: The key role of cordierite in low-pressure anatexis; Canadian Mineral. 32 763-780

Powell R and Powell M 1977 Geothermometry and oxygen barometry using coexisting iron-titanium oxides: a reappraisal; Mineral. Mag. 41 257-263

Sen S K, Bhattacharya S and Acharyya A 1995 A multi-stage pressure-temperature record in the Chilka Lake granulites: The epitome of metamorphic evolution of Eastern Ghats, India? J. Metamorphic Geology 13 287-298 
Sen S K and Bhattacharya S 1997 Dehydration melting of micas in the Chilka Lake khondalites: The link between the metapelites and granitoids; Proc. Indian Acad. Sci. (Earth Planet. Sci.) 106 277-297

Shaw R K and Arima M 1996 Retrograde pressure-temperature path for spinel-bearing metapelites in Rayagada, Eastern Ghats, India; Mineralogy and Petrology 60 41-59
Shaw R K and Arima M 1998 A corundum-quartz assemblage from the Eastern Ghats Granulite Belt, India: evidence for high P-T metamorphism?; J. Metamorphic Geology 16 189-196

Stevens G, Clemens J D and Droop G T R 1997 Melt production during granulite facies anatexis: experimental data from "primitive" metasedimentary protoliths; Contrib. Mineral. Petrol. 128 352-370

MS received 26 August 1999; revised 30 August 2000 